\title{
IS THERE A EUROPEAN BUSINESS CYCLE?
}

\author{
MiCHAEL ARTIS \\ CESIFO WORKING PAPER NO. 1053 \\ CATEGORY 5: Fiscal POLICY, MACROECONOMICS AND GROWTH \\ OCTOBER 2003
}

Presented at Venice Summer Institute, Workshop on “Monetary Unions after EMU,“ July 2003

\footnotetext{
An electronic version of the paper may be downloaded

- from the SSRN website: Www.SSRN.com

- from the CESifo website: www.CESifo.de
} 


\title{
IS THERE A EUROPEAN BUSINESS CYCLE?
}

\begin{abstract}
The paper uses quarterly GDP data for some 30 years up to and including 2001, to examine the identity and development of the European business cycle. Cycles are identified by using a band-pass filter version of the Hodrick-Prescott filter and affiliations are examined using clustering techniques and classical multidimensional scaling applied to cross-correlations and other measures of cyclical sympathy. Twenty-three (23) countries are examined, of which 15 are European. The sample is divided into three 10 -year periods to examine changes in affiliation. The overall verdict is that it is quite hard to discern a homogenous or developing "European cycle" with these data. Put loosely, globalization may be proceeding as fast as Europeanization.
\end{abstract}

JEL Code: N1, E3, C4.

\author{
Michael Artis \\ Economics Department \\ European University Institute \\ Badia Fiesolana \\ Via dei Roccettini 9 \\ 509016 San Domenico di Fiesole (FI) \\ Italy \\ michael.artis@iue.it
}

The author is grateful to Lusine Lusinyan and Ekaterina Vostroknoutova for dedicated research assistance and to Tommaso Proietti for extensive help and advice. 


\section{Introduction}

In this paper we take a look at the issue of whether there can be said to exist a "European" business cycle. The question has been already much studied (including by the present author) in other papers with a similar title ${ }^{1}$. The urge to engage in such study has usually been, of course, to establish whether particular members of the European Union would be well-advised, by the canons of optimal currency area theory, to participate in the EU's monetary union. More often than not, then, the study itself is already confined to European countries and the questions raised have not infrequently involved looking for evidence of closer linkages over time, especially as a result of the drive towards full European Monetary Union and, latterly, its realization. Our perspective is a little different. We are, so to speak, deliberately standing a little further back. We are asking whether there seems to be a cycle we would identify as "European", and if so which European countries belong to it, and how it has emerged over the past 30 years. We do this on the basis of quarterly GDP data rather than the industrial production data which many earlier studies have used for reasons of availability. Our initial approach in the first part of the paper is in the mould of "measurement without theory". That is, we identify the business cycle in a large set of countries - European and non-European - and use heuristic techniques of classical multidimensional scaling and clustering as means of identifying cyclical affiliations. These techniques are applied to familiar measures of synchronization and co-movement. In particular we use cross correlations to measure synchronization and we use the root mean square of the (squared) differences between cross-country cyclical deviates as a measure of the distance between cycles. In the second part of the paper we look at the determinants of business cycle affiliation - what the factors

1 A recent example is Beine et al (2003); earlier ones include Artis and Zhang (1997) and Artis et al (1999) 
are that might bind countries' business cycles together. Our conclusions are relatively restrained. To begin with, we find that the European business cycle is a more elusive phenomenon than we might have expected; whilst some European countries seem to "stick together", there are many which do not. In any case, the US and Japan are often to be found as closely associated with those European countries that do stick together as with others. This is a little bit more than the familiar core and periphery story; it may suggest, to put it as loosely as one can, that globalization is at least as important as Europeanization. When we try to examine those factors that might make for cyclical affiliation we do so from a slightly different angle than has been pursued in most studies to date. We take as a hypothesis the idea that most shocks are common shocks so that business cycle differences are not due, particularly, to asymmetry in the initiating shock, but primarily to asymmetries in the propagation mechanism. We think that those asymmetries may be due to differences in the structure of labour markets, financial markets and product markets. In this paper we can only make the case in respect of the second of these factors; but we regard this as work-in-progress.

The next section (Section 1) of the paper explains the basis on which the business cycles have been identified and the data we have used. The "stylized facts" are documented and the cycles graphically displayed. In Section 2 we develop the principal measures which will be used to identify the cycle, and report results for the whole period. Section 3 then examines how the cycle has developed over the whole period. Results are given for three main subperiods of roughly 10 years each. Section 4 opens the second half of the paper, discussing existing contributions to the task of identifying the determinants of business cycle affiliation. Section 5 provides new results in this vein. Section 6 concludes. There are three appendices.

\section{Stylized facts of the business cycle}

It is common to distinguish two types of business cycle - the so-called "classical" cycle and the "deviation" cycle. In the former, peaks are identified by being followed by absolute declines in output, troughs by absolute increases. Such cycles are, of course, comparatively rare in growth economies and to focus our attention only on these would lead to a paucity of observations. Artis et al (2003) for example identify 
only 3 classical cycles at the Eurozone level in the period from 1970 to 2001 . The deviation cycle, by contrast, deals with deviations in growth from trend and it is this concept of the cycle that we deal with here. After a long period in which it was held that the correct method of detrending could not be decided upon and yet was critical in effect there seems now to be some convergence of opinion on the idea that a bandpass filter is broadly optimal. The design of the filter requires an input in terms of a decision about the frequency of the cycle (and given such a decision the filter is inevitably a sharp one), but this decision does not seem too difficult. Baxter and King (1995) whose work popularized the idea of the band-pass filter suggested that the filter should exclude frequencies lower than those corresponding to a periodicity of 8 years and higher than those corresponding to a frequency of 1.5 years. A disadvantage of the Baxter-King approximation procedure to their ideal filter is that a large amount of data has to be "thrown away" at the end of the sample period as a 3year moving average has to be employed. Here we follow Artis et al (2003) in using a band-pass filter based on combining two Hodrick-Prescott (1997) low-pass filters, again with the aim of isolating the frequencies of interest, namely here those corresponding to the region of periodicities between 1.25 and 8 years. As shown in Artis et al (2003), this band pass filter produces results that are essentially the same as those that can be obtained with the Baxter-King filter but without the damaging loss of data at the end of the sample. (The reader is referred to Appendices D and E of Artis et al for a full discussion of the issues). The series that is isolated by the bandpass filter can be analyzed for its turning points by applying a dating algorithm which imposes phase and cycle duration restrictions (here set at 2 and 5 quarters respectively). The cycles so identified can then be processed for their "stylized facts". In this paper we identify deviation cycles for 22 countries and for the EU15 as an aggregate. Of these 22 countries, 15 are European countries, the total excluding Luxembourg and Greece for reasons of data unavailability but including Switzerland and Norway from outside the EU. Of the 12 countries now in the Eurozone, we include 10 (i.e. again excluding Luxembourg and Greece). Our preferred measure of economic activity is that of real GDP; the full sample period for this variable at a quarterly frequency varies from country to country but predominantly runs from 1970 to 2001. As a data source we used the IMF's International Financial Statistics which necessitated an intervention to correct for the data jump associated with German unification. A data description exercise conducted with STAMP over the whole 
series indicated that the optimal description would involve a shift dummy on the log of the GDP series in 1991:2 and this indicated the best correction to make. Whereas most of the series are given by the IMF in already seasonally adjusted form, this was not true in all cases and for those seasonal adjustment was accomplished by ourselves. The EU15 series was taken from the OECD. Table 1 indicates the full set of countries for which we have quarterly GDP data, and the sample size associated with each. Table 2 then gives the stylized business cycle facts for each of these countries, whilst Chart 1 gives a graphical representation of the cycles.

The stylized facts reported in Table 2 comprise the number of cycles, the average probability of expansion and recession phases, the average duration and amplitude of these phases and their "steepness". 2 The number of cycles identified varies across countries partly because data availability varied across countries, as reported in Table 1; taking account of this there is weak evidence that European countries tend to run to more cycles than the US and for the EU 15 nine cycles are detected in this period as against seven for the US. As can be seen from the accompanying graph (Chart 1), the "number of cycles" has been identified with the number of peaks (or troughs), rather than (necessarily) with the number of complete cycles. ${ }^{3}$ The dating algorithm of the deviation cycle, roughly described above, also insists that a peak (trough) can never be identified at a point which is below (above) trend, even if it should be associated with an inflexion in the rate of change of output relative to trend (this distinguishes the deviation from the growth rate cycle - see Artis et al (2003), Appendix B). By construction the deviation cycle should be a stationary series, so that it is not surprising that average expansion and recession probabilities (which are the fractions of time that the economy is in one or other phase) should be roughly equal at around 0.5 . The average duration, in quarters, of the two phases is also roughly equal at $7-$ 10 quarters, but with a number of outliers - Denmark for example has expansion durations that average only 4 quarters, whilst Mexico's exceed 12. In the same way there is some dispersion of average recession durations, with Norway on only 5 quarters, and Mexico 6. Average amplitudes, measured as the proportionate increase from trough to peak for expansions and from peak to trough for recessions are not at

\footnotetext{
${ }^{2}$ See Harding and Pagan (2001) for a discussion of the stylized facts of the business cycle.
} 
all symmetrical. Expansion amplitudes are generally much higher than recession amplitudes, though the latter are not often negative. "Steepness" is measured as the quotient of amplitude and duration: the relative symmetry of durations and the asymmetry of amplitudes thus reflects in very unequal measures of steepness in expansion as opposed to recessions - the former being very much higher than the latter in all countries.

\section{Section 2. Cyclical affiliations}

In this section we take a first pass at answering the question that forms the title of the paper. How might we recognize a "European" cycle? Many investigators, faced with this type of question, have looked at the cross correlogram of the cyclical deviates at zero phase shift; the practice goes back at least to the early tests of RBC propositions in an international setting (e.g. Backus and Kehoe,1993). This can be thought of as a test for synchronization; it is intuitive and familiar and we repeat the use of this measure here. Table 3 shows the matrix of contemporaneous cross-correlations. Studying this table with the naked eye in search of a "European cycle" reveals some obvious things. The exercise involves looking across the rows and columns of the table. A "European cycle" would be betrayed by European countries having higher cross-correlations with each other than with other non-European countries. On this basis it is clear that if we are to talk about a European cycle we shall have to talk about the European "core", and we shall have to recognize that there are many European countries which are not in this core and, equally, that Japan (and, though perhaps to a lesser extent, the US) may be more closely associated with this core than some of the "peripheral" European countries - Great Britain, Portugal, Ireland, Sweden, Finland and Denmark.

To aid the detection of patterns in the data we have employed two graphical techniques here. Chart 2 represents the results of a classical multidimensional scaling (MDS) exercise applied to the data in table 3. The idea of MDS is to project those data onto a plane forming a "map", from which the proximity of some observations to

\footnotetext{
${ }^{3}$ This issue is more complicated than might be thought. Imagine a cyclical evolution that started from a trough, and described two complete cycles, ending in another trough. Then the number of peaks (2) correctly indicates the number of cycles, whilst the number of troughs (3) overstates it.
} 
others should be obvious. The technique is explained in more detail in Appendix A. The transformation of the data aims to preserve in the Euclidean distance between the objects a relationship to the data shown in Table 3 . Hence, we might hope to find a European cycle depicted as a cluster of European countries huddled close together on the map. However the projection cannot be exact and the goodness of fit statistic in this case is not high, at 37.16. The Chart offers rather weak confirmation of what we already deduced from casual inspection of Table 3.

A somewhat clearer picture emerges from the application of hierarchical ("hard") clustering analysis to these data; the object of the clustering is again the same namely to reveal the associations between country observations. A clustering algorithm starts with a distance matrix showing some measure of dissimilarity between the countries located along the axes; this will be a square matrix with a diagonal of zeroes and symmetric above and below the diagonal. The algorithm then first forms a cluster from the two observations which are closest together; replacing these by another value, the algorithm then proceeds to find the next smallest difference between any two observations (counting the just completed first cluster as one of these) and so on. The initial values entering the distance matrix are in the form of dissimilarities between (in our case) countries in respect of some characteristic (possibly several characteristics) - so the algorithm will cluster together countries which are similar in respect of that characteristic (or set of characteristics). In the case illustrated in Chart 3a, the characteristic, $x_{k i}$, is a measure of the cyclical synchronicity of the country in question with all the other countries. This seems to match fairly well our intuitive idea of what countries forming a European business cycle would have in common - they should have sympathetic business cycle behaviour ${ }^{4}$. Clustering algorithms are long on alternative measures of distance (the measurement of the difference between observations) and on alternative ways to compute the value of a cluster after one has been identified. They are short on measures of significance or adequacy (though some appear in the context of "fuzzy" clustering). In the construction of Chart 3a, we selected the distance measure as the Euclidian distance

\footnotetext{
${ }^{4}$ Nevertheless it might be objected that it is not quite the same thing. In this light we also experimented with alternatives, confining the subscript $\mathrm{j}$ in the expression in the text to Germany for example, or the set of individual EU countries.
} 
(i.e. as $\sqrt{\sum_{k=1}^{22}\left(x_{k i}-x_{k j}\right)^{2}}$ ) and the cluster replacement measure as that of average

linkage. Experimentation with alternative distance measures did not in general reveal any significant difference. The conclusions more tentatively derived from Table 2 are now rather clear. The clustering algorithm reveals, it seems, a cycle cluster based on the US, Canada, Great Britain and Australia and a "European cycle" itself based on two clusters, one involving Germany, Austria, Switzerland and the Netherlands, and the other involving France, Spain, Belgium, Italy and Denmark; but at the level at which these two are joined, there is also Japan. This is, if nothing else, a warning not to invest the notion of a "European" cycle as such with too much that is idiosyncratically European. Other European countries - Ireland, then Finland, Sweden, Portugal and Great Britain are further away and Norway does not seem at all closely related in business cycle terms.

Contemporaneous cross correlation is not the only dimension in which we might want to measure similarity of business cycle experience. Some investigators (e.g., Massman and Mitchell (2002), Barrell and Weale (2003)) have suggested as an alternative the distance between cycles, as might be measured for example by the RMS of the squared differences over a period of time. The suggestion responds to the idea that whilst (for example) synchronization may not change over time, the amplitude of cycles may do so and thus the difference between cycles, for a given degree of synchronization, may increase or diminish. Chart $3 \mathrm{~b}$ repeats the clustering exercise of Chart $3 \mathrm{a}$ for a combination of the cross correlation and distance measures, defined as $\sqrt{\left(1-r_{i j}\right)^{2}+d i s t_{i j}{ }^{2}}$, where $r_{i j}$ is the cross correlation and dist $t_{i j}$ is the RMS distance between the cycles of countries $i$ and $j$. . As in the case of the simple crosscorrelation this measure is computed over all $j$ for each $i$. The result of the adjustment is "fortunate" to the extent that a European cluster is now more clearly defined than before, if still at the expense of exiling Great Britain, Ireland, Finland, Sweden and Portugal among the EU countries from the European block. Japan is now less prominently European!

As we have already seen clustering can be applied to several dimensions of an object at the same time. In the appendix we report the results of clustering over enhanced 
combinations which include further characteristics of cycles, such as those reported as the stylized facts in Table 2. ( It may be noted that, unlike the measures hitherto employed, these further characteristics.require the dating of the cycle to be identified).

How has the European business cycle evolved over time? This question we can try to answer by dividing the full sample into sub-periods. We have chosen relatively long (10-year) sub-samples for this purpose, with breaks that have an institutional resonance: thus $1970-79$ is the pre-ERM period, starting just before the breakdown of Bretton Woods and comprising the subsequent period of generalized floating; 197992 is the ERM period, ending with the Maastricht Treaty whilst the last period distinguished, 1993-2001, marks the post-Maastricht period of transition for some countries to EMU. Since the business cycle itself is the unit of observation it does not seem advisable to investigate much shorter samples than these.

\section{Developments over time}

There are several reasons to expect that the cyclical affiliations of the economies we are examining might change over time. First, there have been changes in the international financial regime. If the first sub-period examined here essentially follows the breakdown of Bretton Woods and the advent of generalised floating, the next sub-period marks the creation of the EMS and its exchange rate mechanism (ERM) for a group of European Union countries (with others intermittently following pegged regimes involving the DM or the ECU, in some cases as a successful apprenticeship for full time engagement in the ERM). The third sub-period marks the experience from the Maastricht Treaty to EMU itself. Although the formal requirements of the ERM were considerably relaxed after the foreign exchange rate crises of 1992 and 1993 with the move to broader $+/-15 \%$ bands of fluctuation the fact is that most countries succeeded in maintaining their bilateral exchange rate fluctuations within the confines of the former narrow bands (Bartolini et al. (2001) give a formal exposition of this remarkable achievement). This, together with the drive to satisfy the Maastricht criteria, should have imposed a degree of homogeneity on the objectives of fiscal and monetary policy. In the meantime, also, trade within the former European Community grew strongly, partly as a result of new initiatives taken, such as that of the initiation of the Single Market. 
Many people would consider that the developments sketched above should be visible in the development of an increasingly coherent European business cycle. But there are a number of reasons why this expectation could be disappointed. One is quite simply that the increased intensity of intra-European relationships in trade and finance has accompanied an increased globalization. Another is that the underlying predictions rest on flimsy foundations. For example, the hypothesis that increased policy homogeneity leads to increased synchronization could easily be reversed. If countries which have been successfully addressing stabilization policy to an idiosyncratic pattern of shocks are led to devote their policies to some other objectives, then a desychronization of business cycles is a likely result. The attraction of the opposite hypothesis is that it addresses the issue of policy shocks; as Kontolemis and Samiei (2000) have argued in the case of the UK, a country may set off on a period of policy experiment and uncertainty which exaggerates business cycle differences. With regard to trade it is well-known that the theoretical prediction of the effect of an increase in trade on business cycle synchronicity is of uncertain sign. All told it is less than clear that any strong position should be taken on the likely shape of developments in regard to the European business cycle. Helbling and Bayoumi (2000), for example have recently argued, in respect of the G-7 countries, that there has been no marked change in their business cycle relationships - they are "all in the same boat", to borrow a phrase from the title of their paper.. We certainly now know that claims that the "Eurozone is a closed economy", put forward at the onset of the recent downturn in the US, need considerable qualification.

The evidence we adduce in this section suggests that whilst there has been quite a lot of movement through the three decades we examine, there is not a monotone movement towards the emergence of a highly coherent and exclusive "European" cycle. In Charts 4 a-c we show the results of an MDS projection for each of the three periods and in Charts $5 \mathrm{a}-\mathrm{c}$ the results of clustering, in both cases referring to a combined cross-correlation-RMS distance measure, computed as for the whole period in the preceding section. The three charts suggest no very clear pattern and most of the regularities that one is inclined to look for are hard to see: the US and UK are not always close together and so on. However the European countries emerge as closest together in the last period (with the exception of Portugal), though even then France 
and Germany are far apart. The clustering exercises suggest for the first period a rather broadly based world cycle, with Finland and Sweden occupying an anomalous position. This anomaly disappears in the second period, in which the US, Canada and Australia (along with Norway and Korea) cluster away from the rest of the world, including all the European countries, with Japan. The last period shows two broadlybased "European" cycles, but one of these is closely associated with the USA. This time, Japan clusters separately. Based on cross-correlations alone the second period is interesting for what is a much cleaner appearance of a European cycle, different from the cluster occupied by the US, Canada and Australia, but in the final period the results are much like those just discussed for the combination measure as shown in Chart 5c. Thus what we seem to find is that the picture for the sub-periods varies considerably over time: this in itself is a reflection of the fact that, in terms of completed cycles, these are very short period of no more than 2 or 3 observations. ${ }^{5}$ There is little to report by way of a clear picture of sustained movement towards the emergence of a European cycle obviously different from the US.

\section{Determinants of business cycle affiliation}

What factors help determine business cycle affiliation? A large part of the literature devoted to this topic has been concerned with trade. It is easy to see that a great deal of trade between two countries may lead to the export or import of a business cycle from one to the other as a straightforward consequence of demand fluctuations: a demand contraction in Germany likely will lead to a reduction in demand in Austria because the reduction in demand in Germany reduces the demand for Austria's exports. But investigators have gone beyond this to consider whether, when trade between countries grows, this might not betoken a specialization rendering the countries more open to asymmetric shocks: this was the basis for Paul Krugman's speculation (Krugman, 1993) that the formation of a currency union could lead to a decrease in business cycle synchronicity. Frankel and Rose (1997) subsequently led a fashion for estimating the effect of trade on synchronicity (which they found to be

\footnotetext{
${ }^{5}$ A fortiori, this suggests that the evidence of the last five years (1995-2001) should be regarded very carefully. For what it is worth, we ran the clustering algorithm on the data for these years, using the combination correlation-RMS distance measure as before. The exercise yields a European cycle based on two large subgroups (which also contain Canada and Australia in one case and the US in another)
} 
positive and large). Some investigators more recently (e.g., Fidrmuc 2001, Grubel et al. 2002), have sought to investigate intra-trade and other trade separately, on the basis that sector-specific shocks should be common shocks where a large amount of intra-trade takes place. Even this might not be sufficient, however. Fontagné and Freudenberg (1999) have drawn attention to the fact that intra-trade itself can be thought of as "vertical" and "horizontal", the one a trade in qualities (Fiats for Mercedes) the other in components (engines for chassis). Taste shifts (demand shocks) could still create asymmetric shocks in the former case though not the latter. Most studies have continued to find a positive association between the trade between countries and the level of their business cycle synchronization regardless of the precise way in which the trade relationship has been modelled, but more recent estimates tend to be more conservative than the original ones.

Our approach here is a little different We depart from the simple idea ("model" would too grand a word) that business cycles are the result of originating shocks feeding into a propagation mechanism. Asynchronous cycles may therefore arise from the interraction of different (non-symmetric) propagation mechanisms with common shocks just as much as they arise from asymmetric originating shocks with similar kinds of propagation mechanisms at work. This possibility is too frequently overlooked; yet we know that there are important features of the propagation mechanism that do differ between countries. Thus we could expect that more or less flexible labour markets will make for less or more persistence in the response to a shock. In a similar way we might argue that financial systems differ in the speed with which shocks are passed through the system. Allen and Gale (2000) have made respectable the comparison of different types of financial system, especially in their distinction between "bank-based" and "market-based' systems. We would expect that shocks might travel at differential speed through systems as different as these paradigms suggest. There should also be a role for product market structure in governing the pass-through of shocks. Part of the propagation mechanism is of course policy; indeed those investigators who strongly prefer to study the synchronization of shocks to that of business cycles implicitly give policy differences the highest rating. In order to implement these ideas we have to innovate the 
measurement of variables, as discussed immediately below. To suppose that all shocks are common and that it is only differences in the propagation mechanism that gives rise to differences in bsuiness cycle timing would be a strong position to take. In order to cater for the probability of asymmetric shocks - or of common shocks which have a strongly asymmetric first impact - we also need to deploy some measures of economic structure.

The estimation procedure to be employed is, as in much work of this type, a panel data estimation, with a weak time dimension: we use averages over the three periods employed in the previous section - 1970-79; 1980-92 and 1993-2001. The panel dimension has been foreshortened however. Instead of exploiting every bilateral pair among the set of countries for which we have data, we concentrate separately upon two bilaterals, those with the US and those with Germany. This is partly because the US and Germany represent the two most commonly quoted "poles of attraction", and also because it allows us to sidestep the issue of fixed effects at least as regards these two countries.

The number and identity of the countries involved is indicated in Table 4. Omissions relative to the longer list of countries that has been analysed in the previous sections are due mainly to data availability problems.

Table 5 gives a list of the variables employed in the study with a note on their provenance. Some comments are in order. First of all, regarding those variables that we identified as factors influencing the propagation mechanism, policy descriptors and a variable measuring product market structure are both missing. The endogeneity problem regarding any policy measure is formidable and we could not find any descriptors of product market structure of the type that we wanted. Labour market flexibility is represented by (potentially time-varying) estimates of the NAWRU; finding a summary measure of "labour market flexibility" is not straightforward. Nickell (1997), for example, cites some seven different variables that researchers quote, including replacement ratios, the ratio of the mimium wage to the average and so on. Potentially it might be possible to use a principal component analysis to obtain a "summary indicator". In the meantime the NAWRU seemed as good summary as any - though the account of how it is constructed gives a high weight to recent actual 
unemployment and hence potentially embodies an endogeneity problem. The variable "financial structure" is measured as the ratio of private credit to stock market value traded, representing then the proportion "bank-based". Among other variables, two represent variables that could be highly correlated with the propensity to be affected by asymmetric shocks - the proportion of manufacturing in GDP and the ratio of net oil imports to GDP. In the case of the trade variable we followed the example of Frankel and Rose in instrumenting it through a gravity equation. EMU and EU dummies were included as was a time fixed effect. In the next section we discuss the results of the analysis of business cycle affiliation that we arrived at using these variables.

\section{Section 5. Results}

Tables 6 and 7 report the panel estimation results for bilateral pairs, first for Germany, then for the US. The LHS variable is the cross correlation of the cyclical deviate for the country concerned and the partner, whether Germany or the US. The tables provide a representative set of results. The variables are entered in one of two forms - either as the value of that variable for the country concerned or in absolute difference from the value of that variable in the core country, Germany or the US. In the light of the discussion earlier the less similar countries are in respect of the variables selected to represent elements of the propagation mechanism, and the less similar they are in exposure to shocks, the lower should be the business cycle cross correlation. One of the results of interest in both tables then is the fact that the variables "relative financial structure" and "relative share of oil imports" are significant with a negative sign. Relative labour market flexibility, on the other hand, did not seem to prove significant. In Table 7 the level of the NAWRU in the partner country, but not its relative value, proves to exert a significantly negative effect. In both tables, the column of results (8) indicates that one country - in the case of Germany this is Austria, in the case of the US, it is Canada - proved highly important for the sign and significance of the trade variable. In Table 6 the omission of Austria allows for a significant negative coefficient to appear on the trade variable; in Table 7, the omission of Canada serves to remove the otherwise high level of significance which is attached to this variable. 
Thus these results appear to confirm the value of the financial structure variable in explaining business cycle affiliation, whilst the role of trade is more ambiguous. This result for financial structure is novel and provocative. Clearly, more can be done to extend and refine these results. A number of the variables that appear important do not vary much through time, although they may do so over the cross-section, so that panel estimation is the ideal framework. Indeed, one obvious further step to take is to exploit fully the advantages of the panel by including all bilateral pairs of countries, increasing greatly the number of observations. ${ }^{6}$

\section{Section 6 Conclusions}

In this paper we have sought to explore some aspects of the phenomenon of "business cycle affiliation". First we investigated how far it seems reasonable to talk about a "European business cycle". We did this on the basis of defining the deviation cycle in GDP for the European countries, together with a number of others. Most other papers in this area use industrial production data and tend to look more exclusively at the European countries. We could not make a strong finding of a growing identification of an exclusively European cycle. Portugal, Sweden, Denmark, the UK and Ireland are frequent exceptions to any European grouping among the EU countries whilst outside the group Switzerland often is associated with the group of core countries, whilst Norway is not. Japan is often as strongly associated with the core European countries as are many other European countries, as is often the US. These findings are in tune with recent suggestions to the effect that a world cycle reasserted itself strongly with the last US downturn, at the end of 2000. To the extent that they differ from other received views, the reasons might lie in the choice of GDP data rather than industrial production data, the precise periods chosen for analysis and the centre of gravity of the analysis. We did not start with the question whether the European cycle has become closer and better synchronized, but rather with the question whether a European cycle can be clearly identified. On our analysis we have to return a qualified verdict - it is not so clearly separate from other countries' cycles and a

\footnotetext{
${ }^{6}$ We took a partial step towards this by pooling the US and German pairs which we have discussed in Tables 6 and 7. The not-unexpected result is that where the signs of variables differed but might be in one or other case significant, upon pooling that significance disappears; and where - as in the case of relative financial structure - the two cases separately delivered significant results of the same sign that result is confirmed, with coefficients and significance levels both more or less averaging the previous.
} 
number of European countries don't belong to it. To repeat an earlier phrase, putting it as loosely as possible, our findings are compatible with globalization proceeding just as fast as Europeanization. In the second part of the paper we turned to the issue of how business cycle affiliations might be explained. As the business cycle can be viewed as the result of a propagation mechanism imposed on a shock, business cycle asymmetries might be due to common shocks with dissimilar propagation mechanisms as much as to asymmetric shocks accompanied by similar propagation mechanisms. This led us to introduce into a restricted panel data estimation some variables that might be held to typify key elements in the propagation mechanism, descriptors of financial market structure and of labour market structure. Of these the former proved highly significant. This finding should be tested in a more developed framework.

\section{Appendix A. Classical Multidimensional scaling (MDS)}

In the paper we have used the technique of classical multidimensional scaling (MDS) as a heuristic device to register the idea of proximity visually. The technique allows us to reduce a set of measures of (dis)similarity in several dimensions to a map in two dimensions, creating two orthogonal axes with reference to which each object (country in our case) can be placed. In principal coordinates analysis (PCO) to which MDS is related, each dimension maximises the remaining variance, so that in practice the first two principal components are all that need to be calculated. The assumption is that the remaining components offer little added explanation. More precisely, the goal of classical MDS is, given the information specified in the (dis)similarity matrix, to construct a so-called configuration matrix $X$, for which the Euclidean interpoint distances $d_{i j}$ approximate the dissimilarities.

Suppose $D$ is the proximity-matrix based on the input distances, $X$ is the configuration matrix of coordinates in the map, into which the objects are to be projected, and $q$ is 
the number of dimensions in the map, i.e. here $q=2$. Define $B=X X^{\prime}$, then

$$
\begin{gathered}
b_{i j}=\sum_{k=1}^{q} x_{i k} x_{j k} \\
d_{i j}{ }^{2}=\sum_{k=1}^{q}\left(x_{i k}-x_{j k}\right)^{2}=\sum x_{i k} x_{i k}+\sum x_{j k} x_{j k}-2 \sum x_{i k} x_{j k} \\
=b_{i i}+b_{j j}-2 b_{i j}
\end{gathered}
$$

from which

$$
b_{i j}=-1 / 2\left(d_{i j}{ }^{2}-d_{i .}{ }^{2}-d_{. j}{ }^{2}+d_{. .}{ }^{2}\right)
$$

where terms with dots in the subscript are partial or overall means of elements $\left\{d_{i j}\right\}$. As showed in Torgerson (1952)

$$
B=X X^{\prime}=P \Lambda P^{\prime}=P \Lambda^{0,5} \Lambda^{0.5} P^{\prime}
$$

where $P$ is the matrix of eigenvectors of the matrix $B$ and $\Lambda$ is the diagonal matrix with its eigenvalues on the main diagonal. Hence, the matrix of coordinates in the map is given by

$$
X=P \Delta^{0,5}
$$

How well the MDS procedure performs can be assessed by a goodness-of-fit type of test, which calculates the share of the sum of the first two biggest eigenvalues in the total sum of eigenvalues taken in absolute value, and is given by :

$$
G o F=\frac{\sum^{p^{*}} \lambda_{i}}{\sum^{p}\left|\lambda_{i}\right|}
$$




\section{Appendix B. Clustering applied to the stylised facts}

Chart B1 uses all the "stylized facts" (except for the number of cycles) recorded for the business cycle in table 2 as a set of charcateristics to which to apply the clustering algorithm. A composite measure was created, on the lines of the combination correlation + distance measure, all variables being standardized to mean zero, unit variance to begin with. It is notable that as far as the stylized facts go, Ireland and Portugal are the outliers, together with Korea. Most European countries are like Canada and the US.

\section{Appendix C. Whatever happened to Artis and Zhang?}

The findings in the main text may appear to be at variance with the prediction that many observers would have said was implicit in the findings of Artis and Zhang (1997). In that paper the authors took industrial production deviation cycles estimated by the OECD on the basis of a modified NBER algorithm and showed the cross plots of the cross correlations of those cyclical deviates vis-a-vis the US and vis-a-vis Germany for a sequence of three periods. The first of these was typified as a "preERM period" (1961:1 to 1979:3), the second as post-ERM (1979:4 to 1993:12). The interest in the picture was that where the observations for the first period suggested a broad "world cycle", in the second a number of countries could be seen as having moved strongly towards a stronger affiliation with Germany, with Germany the US themselves much less closely related. The UK was a prominent exception, with the European countries that had moved towards a stronger identification with Germany being those that were associated with the ERM. It might have been thought that this movement would be strengthened in subsequent years. Figures $\mathrm{C} 1-\mathrm{C} 3$ show that this has not been so. These figures plot the cross correlations of the cyclical deviates of industrial production, again as identified by the OECD, now for three periods. The first of these is labelled the pre-ERM period (Figure C1), and the world cycle phenomenon seems again a loosely reasonable characterization. In the second period 
(Figure C2), as in the original paper, a number of European countries have moved above the line - leaving the UK and the Northern "periphery" below the line. In the third period however (Figure C3) matters look rather different. The US and Germany are now themselves highly correlated and it makes no sense to speak of distinctive German affiliation.

Figures C4-C6 use the metric developed earlier in this paper - cross correlations from GDP deviation cycles. Figure C4 again suggests the "world cycle" feature of the preERM period, as does Figure 6. By contrast in the intermediate (ERM) period Figure C5 shows a very low (negative) correlation between Germand and the US, with some countries - Canada, Finland the UK for example - pulled well away from the $45^{\circ}$ line, but most of them staying fairly close. This is a more muted picture than the one given by the preceding industrial production-related analysis. Yet in both the contrast is greatest between the second and the first or third period than between the first and third. Thus a "pro-European" description would have to say that when the chips are down - i.e. when Germany and the US part company - the "European-ness" of (some) European countries shows itself in a more positive adherence to Germany than to the US. But, most recently, the US and Germany have been, in the fortunate phraseology of Helbling and Bayoumi (2003) "in the same boat".

\section{Acknowledgments}

The author is grateful to Lusine Lusinyan and Ekaterina Vostroknoutova for dedicated research assistance and to Tommaso Proietti for extensive help and advice.

\section{References}

Allen, F. and D. Gale (2000). Comparing Financial Systems. Cambridge, MA: MIT Press..

Artis, M.J. and W. Zhang (1997) "International Business Cycles and the ERM: Is There a European Business Cycle?" The International Journal of Finance and Economics, 2, 1099-1158

Artis, M.J., Krolzig, H-M and J. Toro (1999) “ The European Business Cycle”, CEPR Discussion Papers, No. 2242. 
Artis, M.J., Massimiliano, M. and T.Proietti (2003) "Dating the Euro Area Business Cycle" CEPR Discussion Papers, No 3696

Backus, D. and P.Kehoe (1993) "International Evidence of the Historical Properties of Business Cycles", American Economic Review , 82 (4), 864-88.

Ballabriga, F., Sebastien, M. and J.Vales (1999) "European Asymmetries", Journal of International Economics, 48, 233-253

Barrell, R. and M. Weale (2003) "Designing and Choosing Macroeconomic Frameworks: the position of the UK after four years of the Euro", Oxford Review of Economic Policy, 19, Spring, 132-148.

Bartolini, L. and A. Prati (1998) "Soft Exchange Rate Bands and Speculative Attacks: Theory, and Evidence from the ERM since August 1993" IMF Working Papers, $98 / 156$.

Beine, M., Candelon, B. and K.Sekkat (2003) "EMU membership and business cycle phases in Europe: Markov-swiching VAR analysis", Journal of Economic Integration, 18, 214-242.

Fidrmuc, J (2001) "The Endogeneity of the Optimal Currency Area Criteria, IntraIndustry Trade and EMU Enlargement", Centre for Transition Economies, Katholeike Universitiet, Discussion Papers, No 106/2001

Fontagné L. and Freudenberg M. (1999), "Endogenous symmetry of shocks in a monetary union”, Open Economies Review, 10, July, 263-288.

Frankel J. and A. Rose (1997), "Is EMU more justifiable ex-post than ex-ante?" European Economic Review, 41, 753-760

Gruben, W., Koo, J. and E.Mills (2002) How Much Does International Trade Affect Business Cycle Synchronization?", Federal Reserve Bank of Dallas

Working Papers, No 0203

Harding,D. and A. Pagan (2001) "Extracting, Analysing and Using Cyclical Information", mimeo, August.

Helbling,T. and T. Bayoumi (2003) "Are They All in the Same Boat? The 2000-2001 Growth Slowdown and the G-7 Business Cycle Linkages”, IMF Working Papers $03 / 46$

Hodrick, R. and E. Prescott (1997) "Post-war US business cycles: an empirical investigation", Journal of Money, Credit and Banking, 29, 1-16.

Imbs, J. (2003) "Trade, Finance, Specialization and Synchronization", CEPR Discussion papers, No 3779. 
Kalemli-Ozcan, S., Sorensen B. and O.Yosha (2001) "Economic Integration, Industrial Specialization and the Asymmetry of Macroeconomic Fluctuations", Journal of International Economics, 55, 107-137.

Kenen, P.B. (2002) "Currency Unions and Policy Domains" in (eds.) Andrews, D., Henning, C. , and L. Pauly: Governing the World's Money.. Ithaca, N.Y. ; London : Cornell University Press

Kontolemis Z. and H. Samiei (2001), "The UK business cycle, monetary policy and EMU entry”, IMF Working Papers, WP/00/210

Krugman P. (1993), "Lesson from Massachusetts for EMU", in (eds.), Torres F. and F. Giavazzi: Adjustment and Growth in the European Monetary Union, Cambridge: Cambridge University Press.

Massman, M. and J.Mitchell (2002) "Have UK and Eurozone Business Cycles become more correlated?", National Institute Economic Review, No 182, October, 5871 .

McKinnon R.I. (1963), "Optimum currency areas", American Economic Review, 53 September, 717-725.

Mundell R.A. (1961), “A theory of optimum currency areas”, American Economic Review, 51 (September), 657-665.

Nickell, Stephen, 1997. "Unemployment and Labor Market Rigidities: Europe versus North America," Journal of Economic Perspectives, Vol. 11 (3) pp. 55-74

Torgerson, W. S. (1952), "Multidimensional Scaling: I. Theory and Method", Psychometrika, 17:401-- 419. 
Chart 1: Business cycles - GDP data and deviation cycles
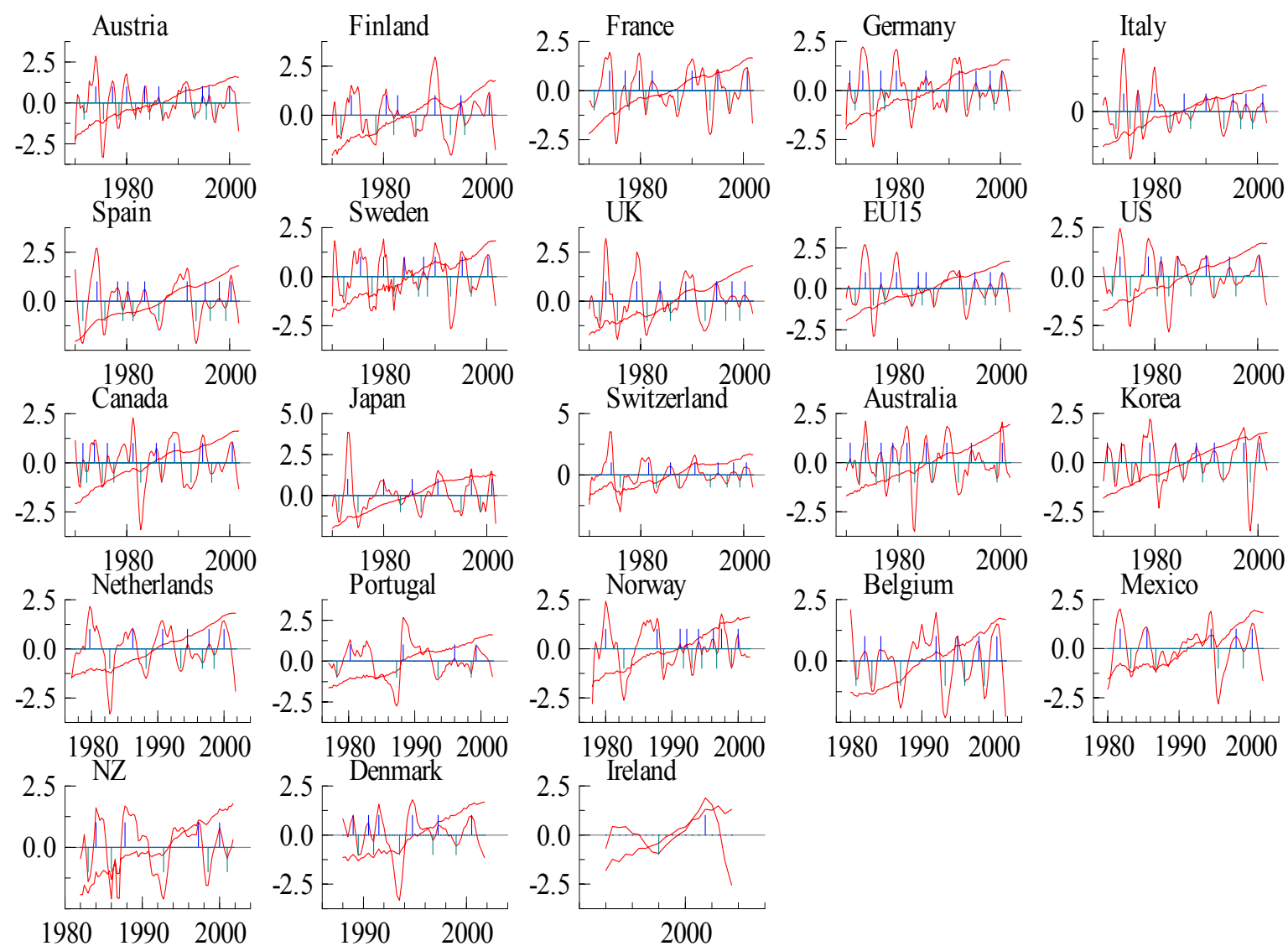
Chart 2: Classical MDS based on the cross-correlation measure, full sample 1970-2001

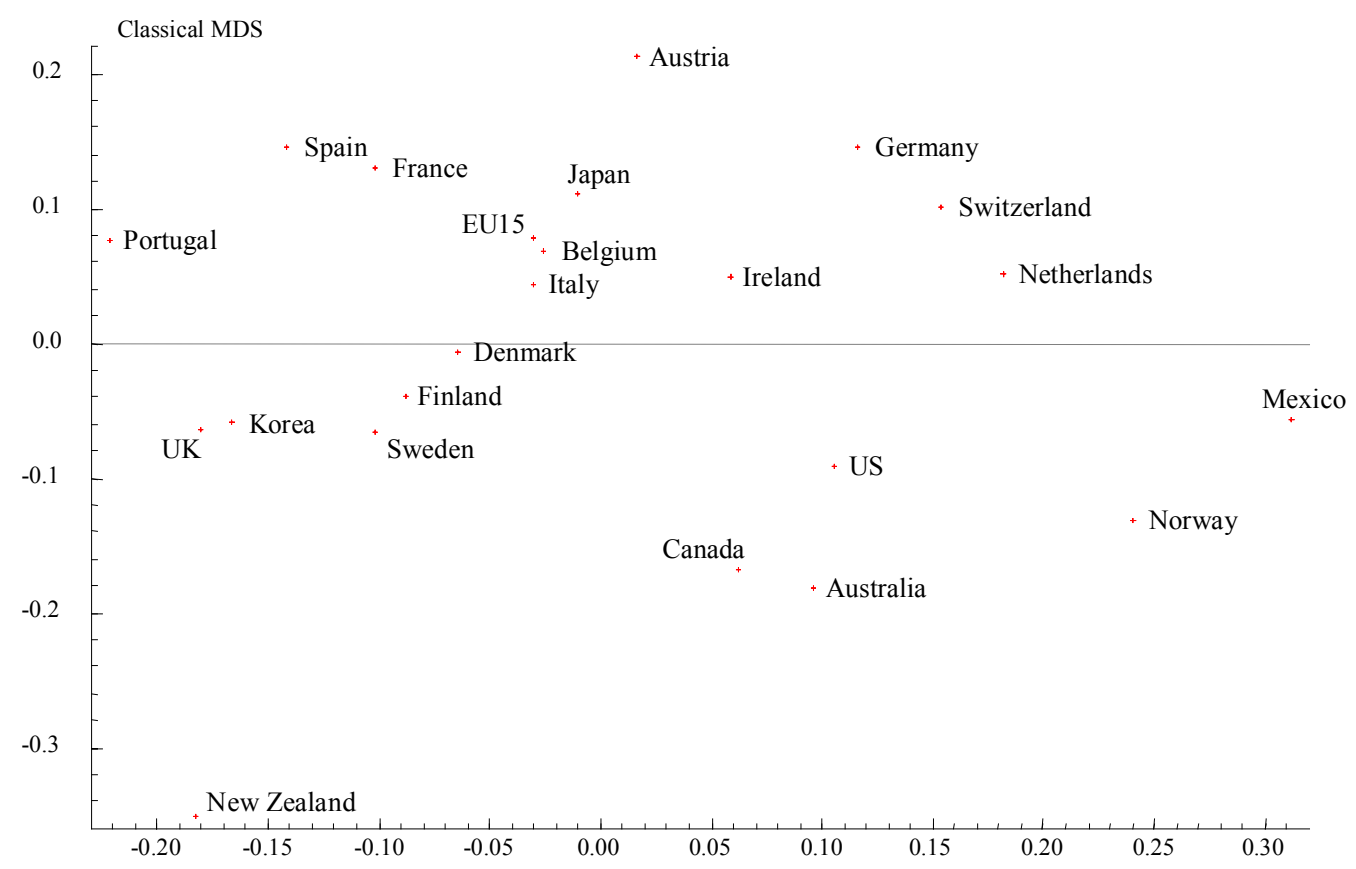


Chart 3a: Hierarchical average-linkage cluster tree (dendrogram) using Euclidean (L2) dissimilarity measure based on the cross-correlation measure, full sample 1970-2001

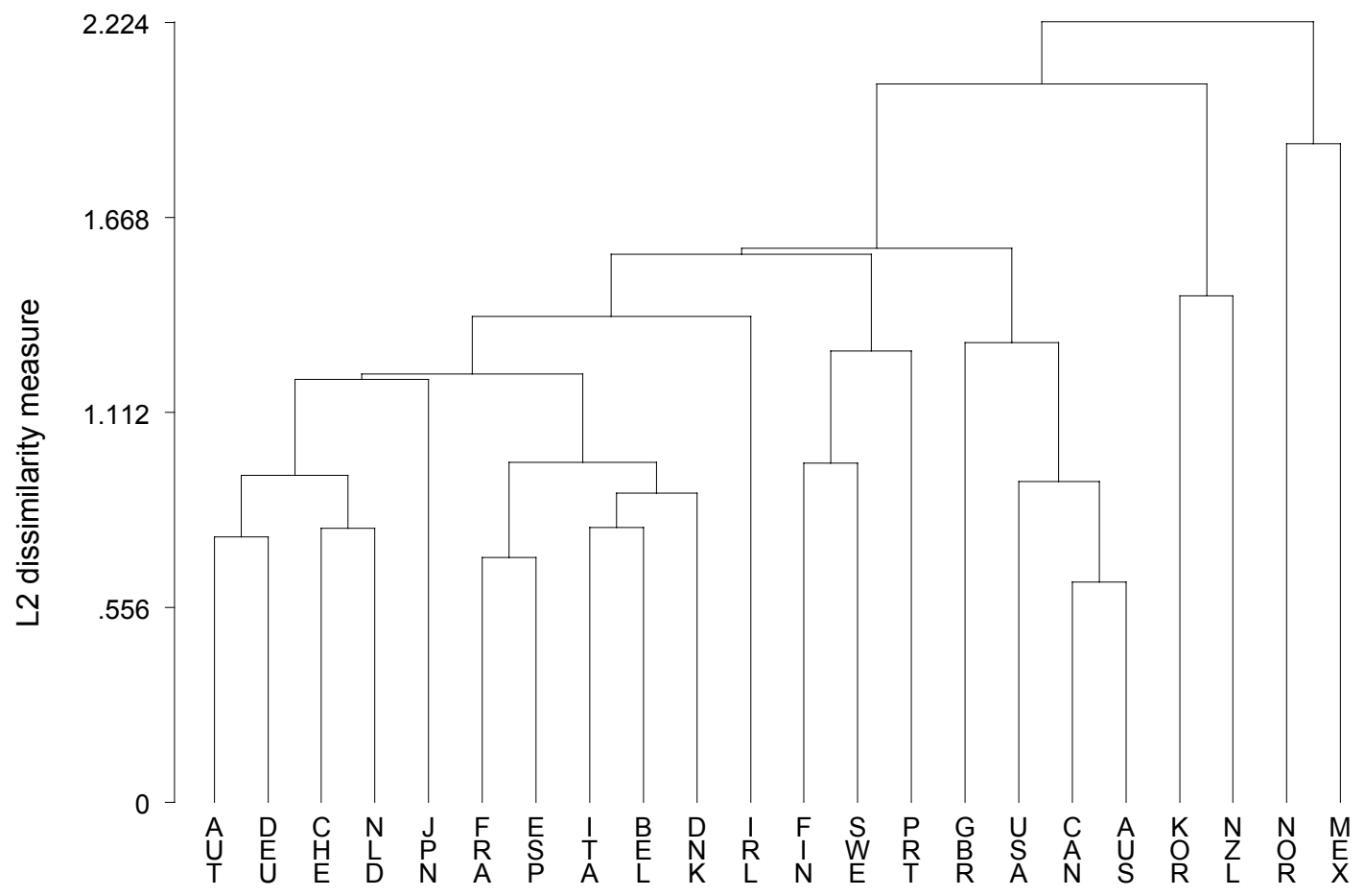

Chart 3b: Hierarchical average-linkage cluster tree (dendrogram) using Euclidean (L2) dissimilarity measure based on the combined cross-correlation and distance measures, full sample 1970-2001

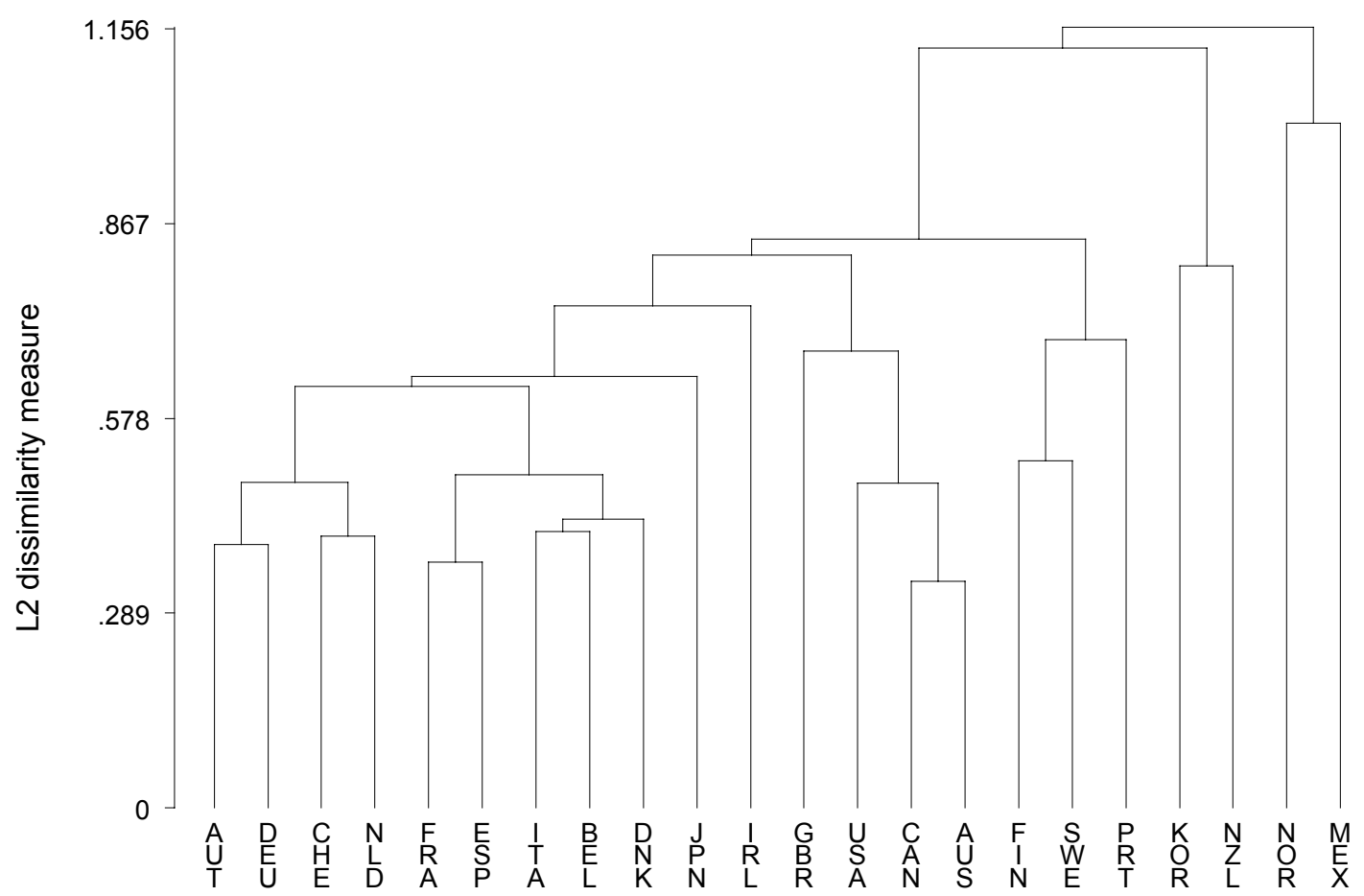


Chart 4a: Classical MDS based on the combined cross-correlation and distance measures, 1970-1979

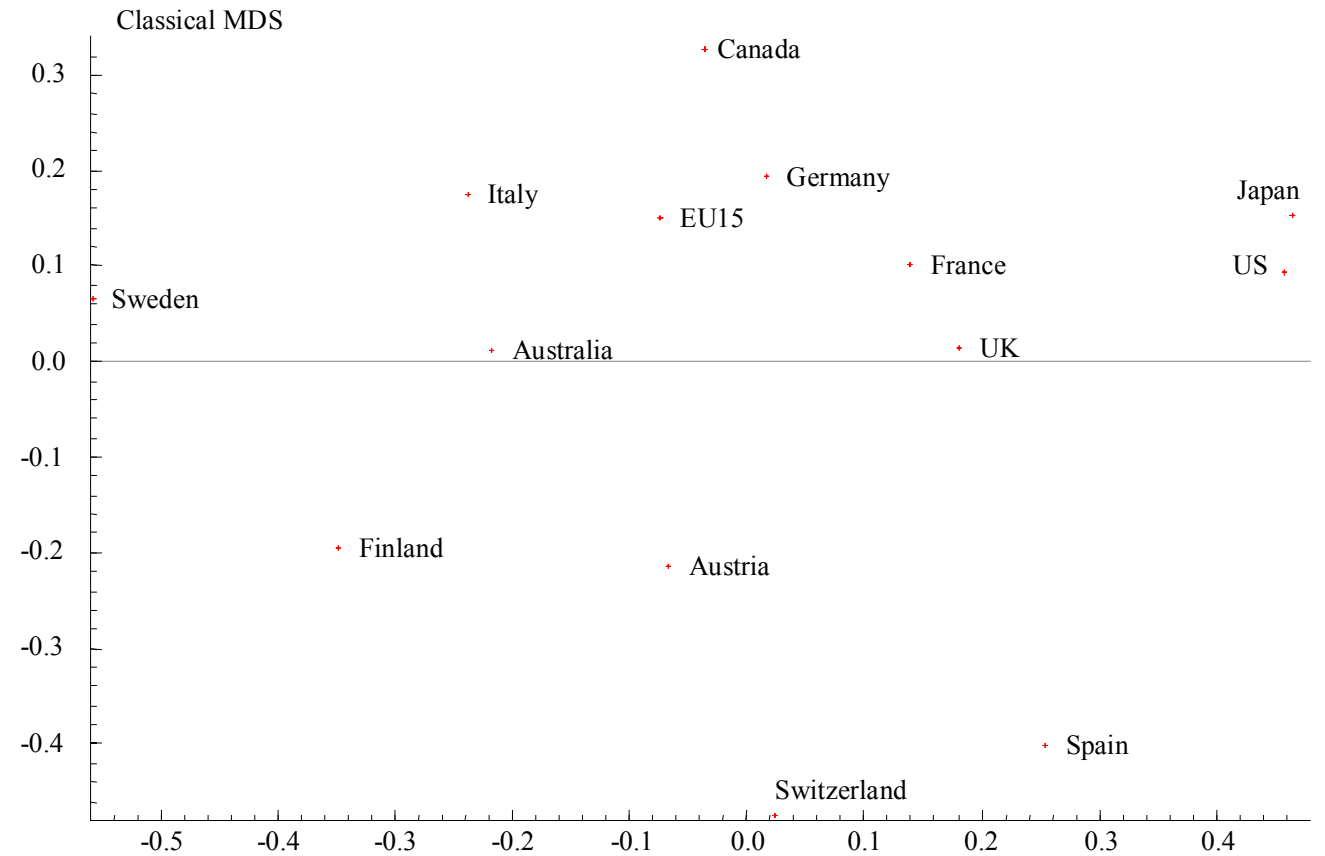

Chart 4b: Classical MDS based on the combined cross-correlation and distance measures, 1980-1992

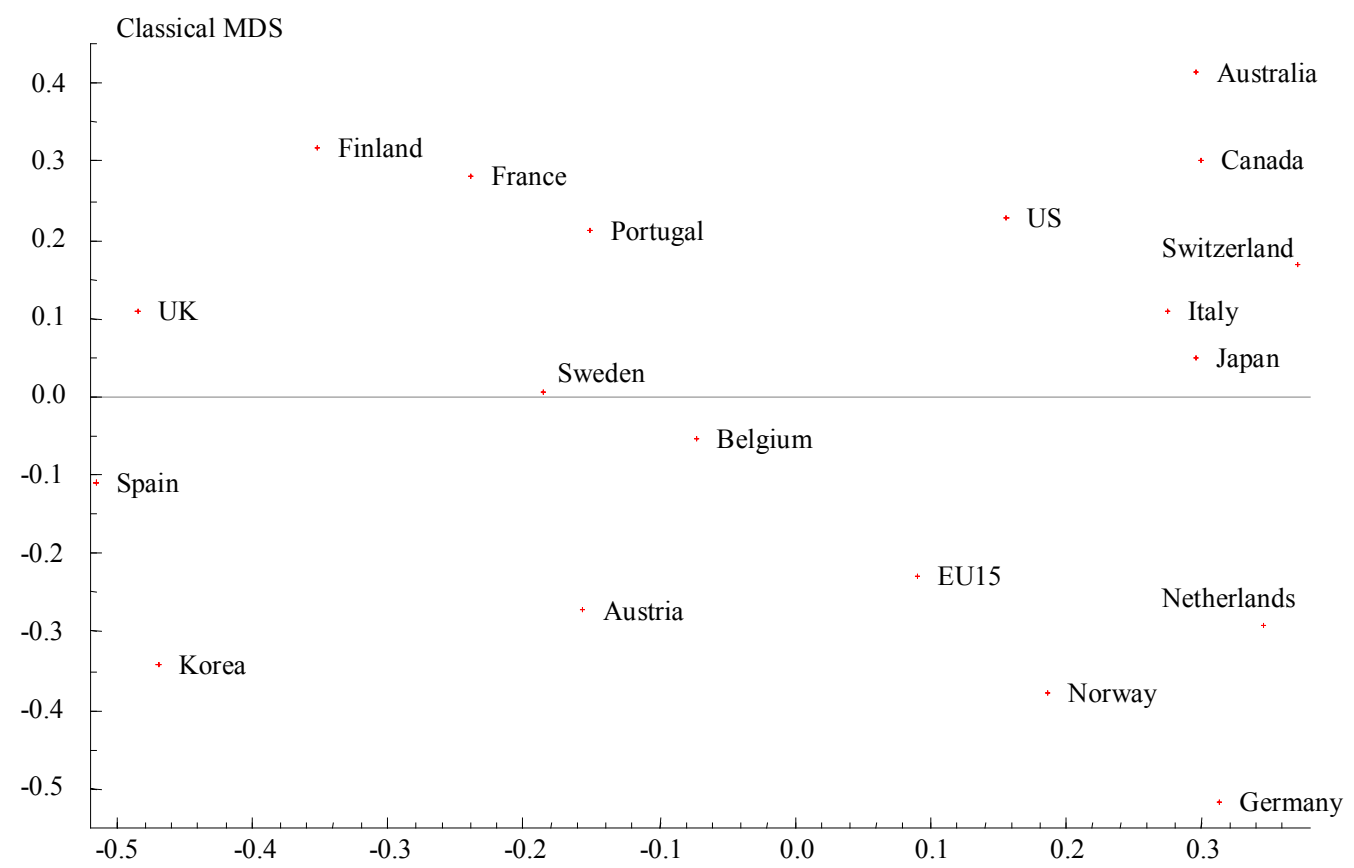


Chart 4c: Classical MDS based on the combined cross-correlation and distance measures, 1993-2001

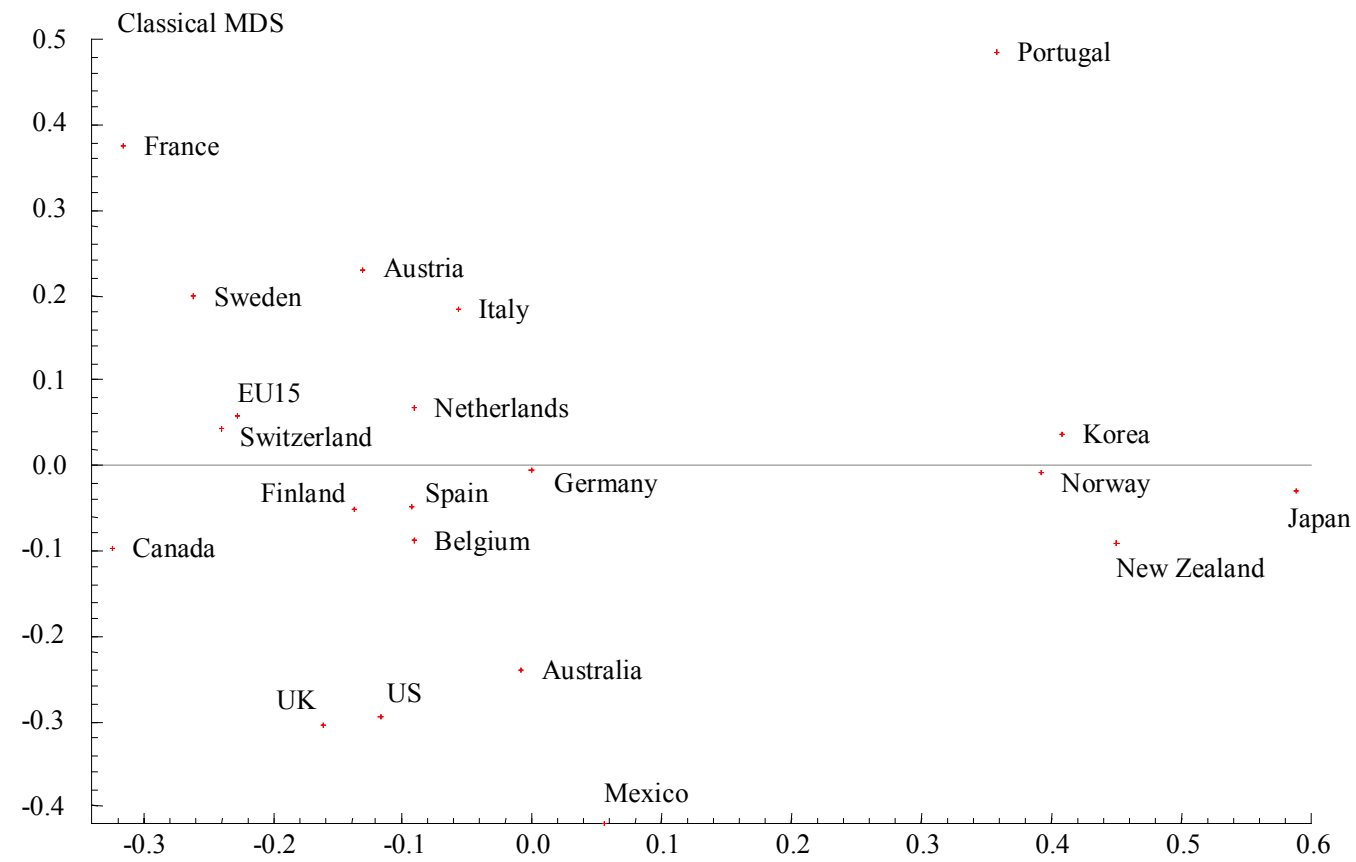

Chart 5a: Hierarchical average-linkage cluster tree (dendrogram) using Euclidean (L2) dissimilarity measure based on the combined cross-correlation and distance measures, 1970-1979

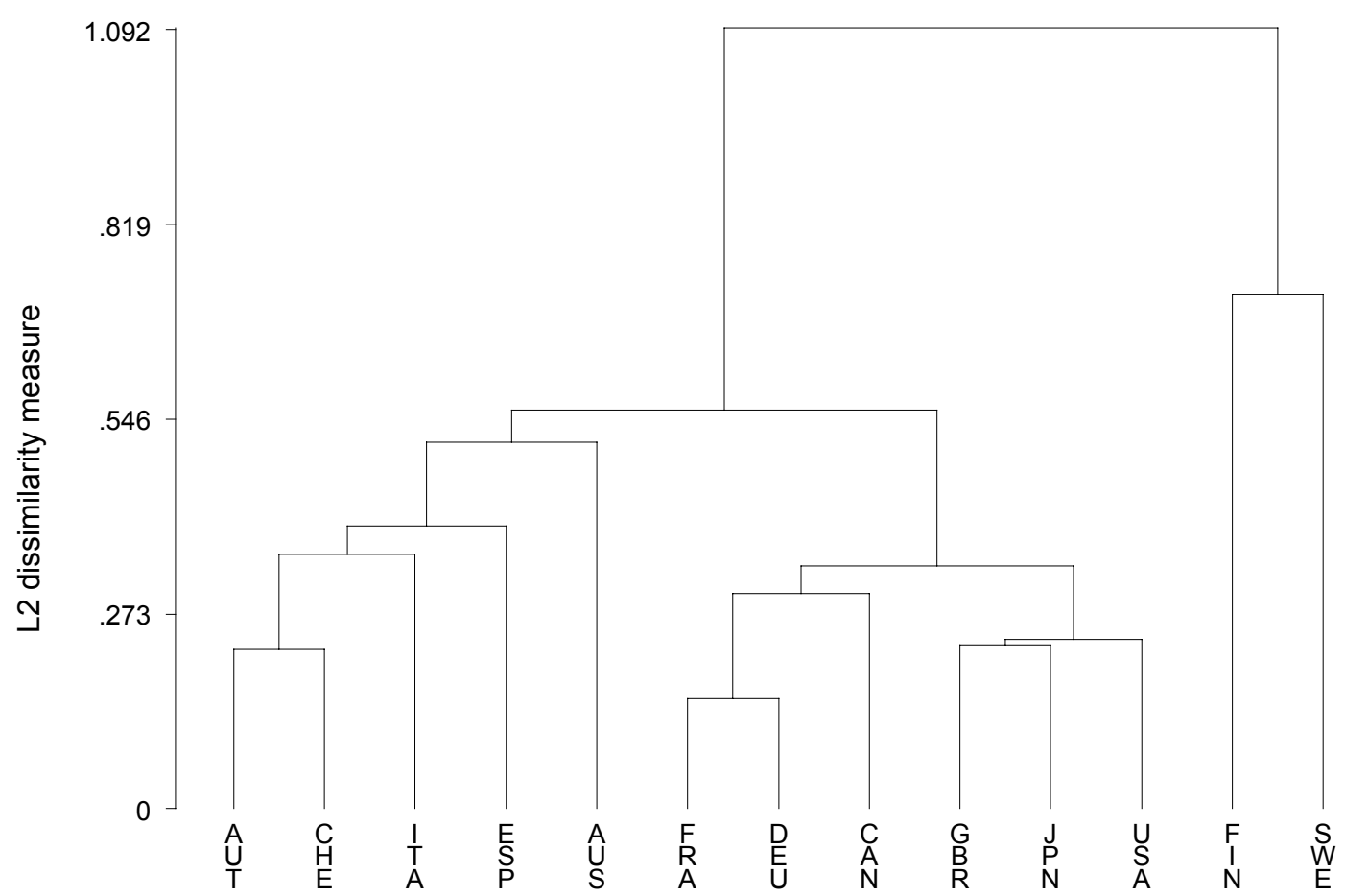


Chart 5b: Hierarchical average-linkage cluster tree (dendrogram) using Euclidean (L2) dissimilarity measure based on the combined cross-correlation and distance measures, 1980-1992

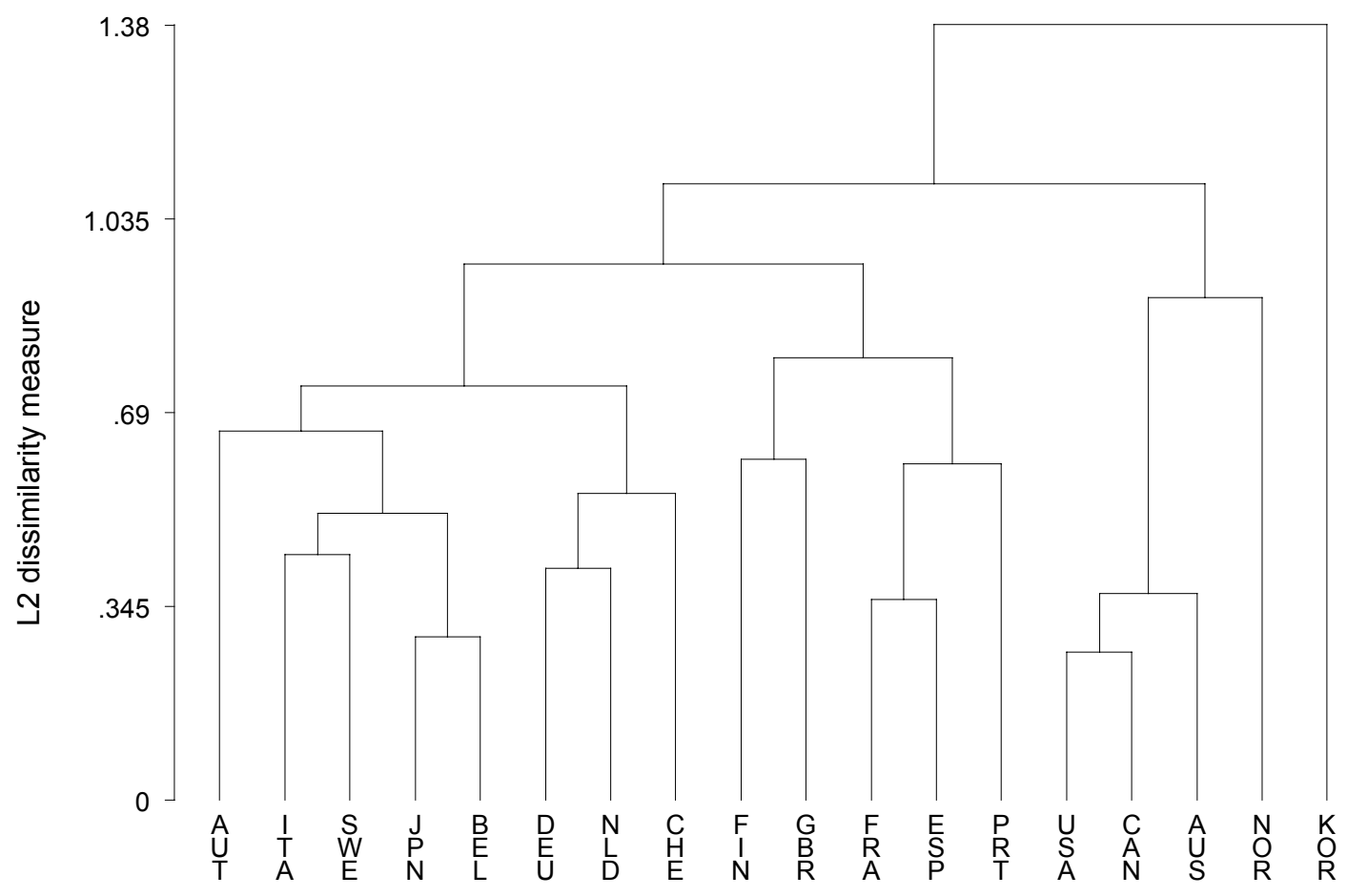

Chart 5c: Hierarchical average-linkage cluster tree (dendrogram) using Euclidean (L2) dissimilarity measure based on the combined cross-correlation and distance measures, 1993-2001

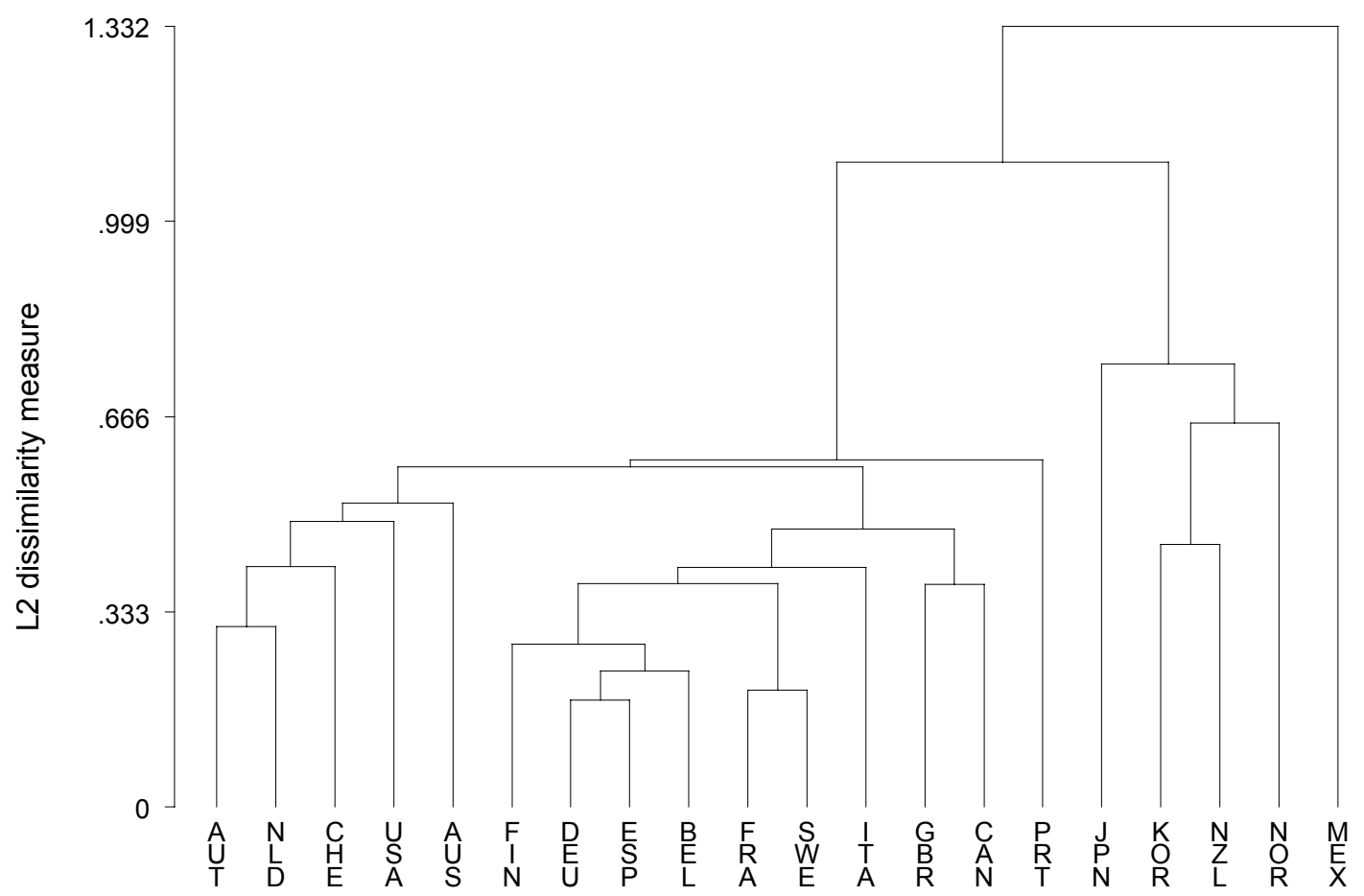


Table 1: Country sample in MDS and cluster analyses

\begin{tabular}{rlcc}
\hline & Country & ISO-Code & Sample size \\
\hline \hline 1 & Austria & AUT & $1970-2001$ \\
2 & Finland & FIN & $1970-2001$ \\
3 & France & FRA & $1970-2001$ \\
4 & Germany & DEU & $1970-2001$ \\
5 & Italy & ITA & $1970-2001$ \\
6 & Spain & ESP & $1970-2001$ \\
7 & Sweden & SWE & $1970-2001$ \\
8 & United Kingdom & GBR & $1970-2001$ \\
9 & EU15 & & $1970-2001$ \\
10 & US & USA & $1970-2001$ \\
11 & Canada & CAN & $1970-2001$ \\
12 & Japan & JPN & $1970-2001$ \\
13 & Switzerland & CHE & $1970-2001$ \\
14 & Australia & AUS & $1970-2001$ \\
15 & Korea & KOR & $1970-2001$ \\
16 & Netherlands & NLD & $1977-2001$ \\
17 & Portugal & PRT & $1977-2001$ \\
18 & Norway & NOR & $1978-2001$ \\
19 & Belgium & BEL & $1980-2001$ \\
20 & Mexico & MEX & $1980-2001$ \\
21 & New Zealand & NZL & $1982-2001$ \\
22 & Denmark & DNK & $1988-2001$ \\
23 & Ireland & IRL & $1997-2001$ \\
\hline
\end{tabular}





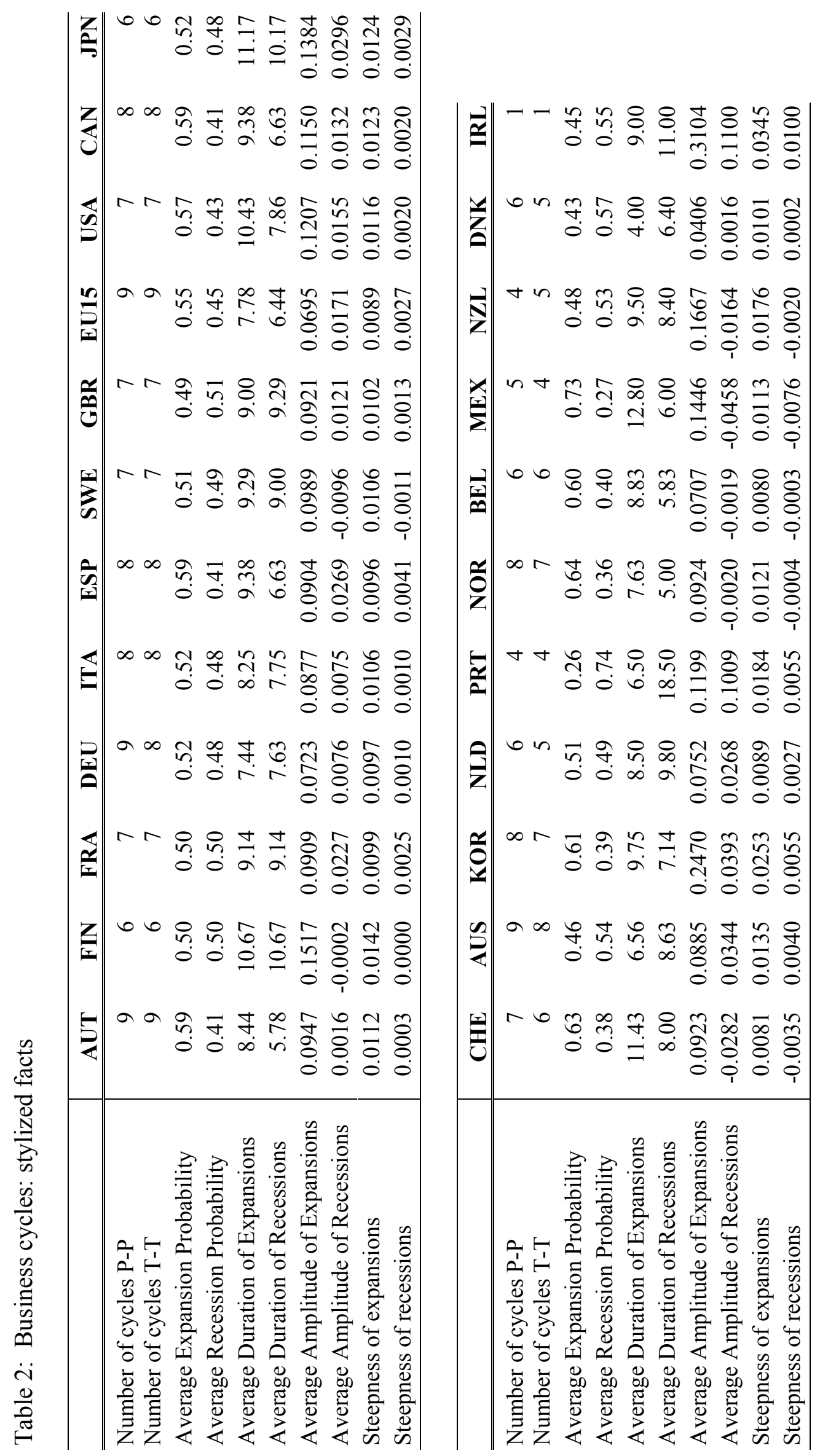





$$
\begin{aligned}
& \text { 光官 } \\
& \text { 零 } \stackrel{0}{0} \stackrel{\infty}{0}
\end{aligned}
$$

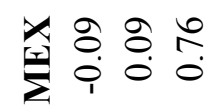

$$
\begin{aligned}
& \text { 궀 궁 त्ञ }
\end{aligned}
$$

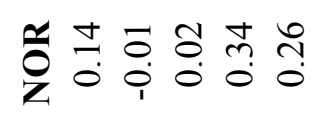

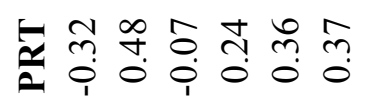

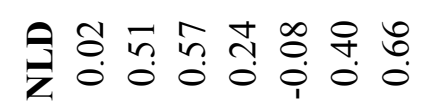

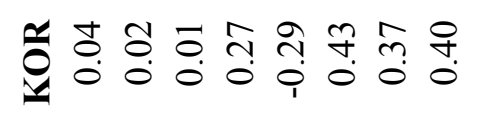

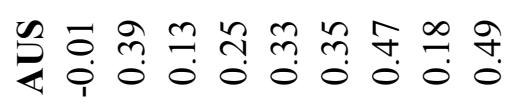

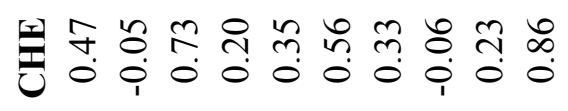

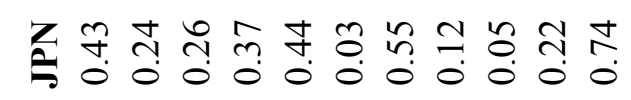

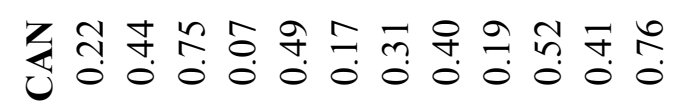

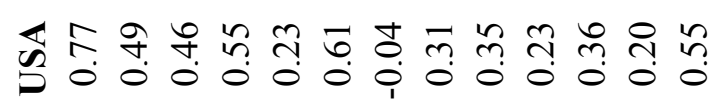

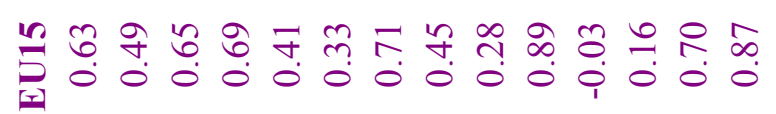

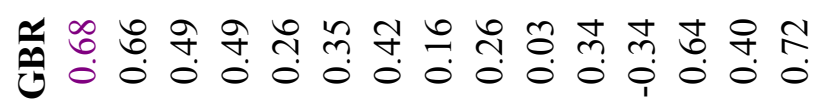

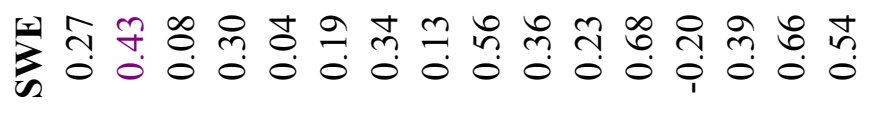

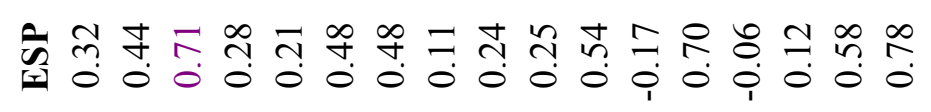

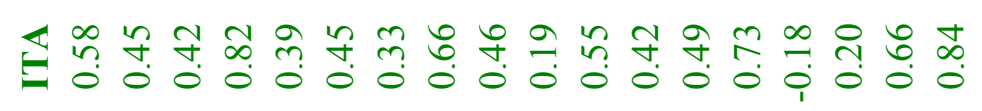

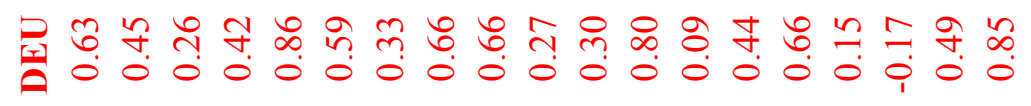

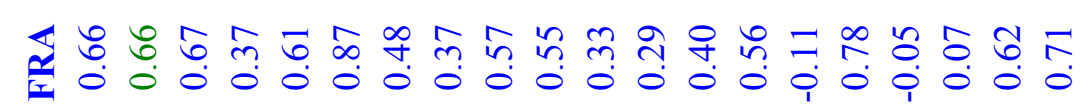

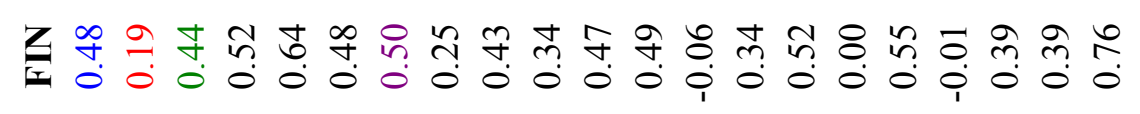

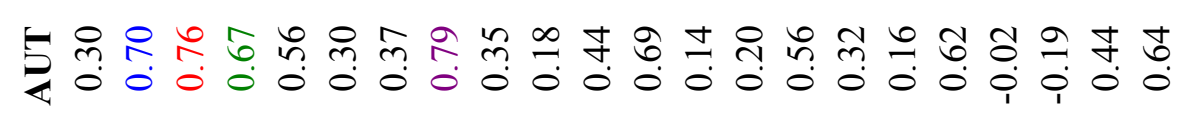
尚

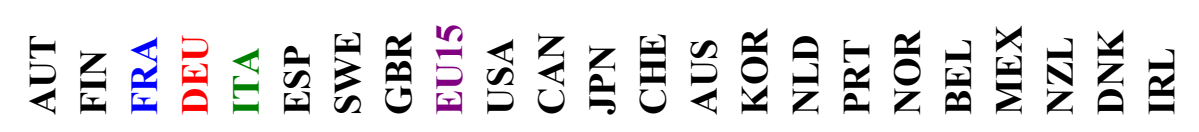


Table 4: Country sample in panel regression analysis

\begin{aligned} & \hline Country \\ & \hline 1 Austria \\ & 2 Finland \\ & 3 France \\ & 4 Germany \\ & 5 Italy \\ & 6 Spain \\ & 7 Sweden \\ & 8 United Kingdom \\ & 9 US \\ & 10 Canada \\ & \hline\end{aligned}


Table 5: Definitions and sources of the data used in panel regression analysis

\begin{tabular}{|c|c|c|c|c|}
\hline Variable name & Data & $\begin{array}{c}\text { Frequency } \\
\text { and time } \\
\text { period } \\
\end{array}$ & Definition & Source \\
\hline Trade share & $\begin{array}{l}\text { Trade intensity with } \\
\text { DEU, USA }\end{array}$ & $\begin{array}{l}\mathrm{Q} \\
1970-2001\end{array}$ & $\begin{array}{l}\text { Trade with DEU/ } \\
\text { (total trade of } \\
\text { DEU+total trade of } \\
\text { the country); same } \\
\text { for USA }\end{array}$ & $\begin{array}{l}\text { Direction of } \\
\text { Trade } \\
\text { Statistics }\end{array}$ \\
\hline Trade instrumented & $\begin{array}{l}\text { Fitted values from IV } \\
\text { estimation }\end{array}$ & & $\begin{array}{l}\text { Bilateral trade with } \\
\text { DEU or USA, } \\
\text { instrumented using } \\
\text { language, common } \\
\text { border, and distance } \\
\text { (following Frankel } \\
\text { and Rose, 1998) }\end{array}$ & \\
\hline $\begin{array}{l}\text { Labor Market } \\
\text { Flexibility }\end{array}$ & $\begin{array}{l}\text { NAWRU (non- } \\
\text { accelerating wage rate } \\
\text { of unemployment) }\end{array}$ & $\begin{array}{l}\text { A } \\
1970-2001 \\
\text { (CAN, DEU, } \\
\text { ESP, USA, } \\
\text { ITA), } \\
1973-2001 \\
\text { (AUT, FRA) } \\
\text { 1971-2001 } \\
(\mathrm{GBR})\end{array}$ & $\begin{array}{l}\text { ITA - no } \\
\text { imputations; } \\
\text { AUT, FRA, GBR - } \\
\text { constant-interpolated } \\
\text { missing values; } \\
\text { EU, FIN, SWE - } \\
\text { recalculated based on } \\
\text { the NAWRU } \\
\text { formula, for the } \\
\text { whole period }\end{array}$ & $\begin{array}{l}\text { OECD, } \\
\text { Holden and } \\
\text { Nymoen } \\
(2001) \text { - for } \\
\text { Nordic } \\
\text { countries; } \\
\text { Fagan et al. } \\
(2001) \text { - for } \\
\text { EU }\end{array}$ \\
\hline Industrial Structure & $\begin{array}{l}\text { Share of GDP } \\
\text { contributed by } \\
\text { manufacturing }\end{array}$ & $\begin{array}{l}\text { A } \\
1980-1997\end{array}$ & $\begin{array}{l}\text { Base year (1995) } \\
\text { percentage of } \\
\text { manufacturing is } \\
\text { extrapolated on the } \\
\text { industrial production } \\
\text { and divided by } \\
\text { extrapolated output }\end{array}$ & OECD \\
\hline $\begin{array}{l}\text { Share of oil } \\
\text { imports }\end{array}$ & Oil net imports/GDP & $\begin{array}{l}\text { A } \\
1960-2000\end{array}$ & $\begin{array}{l}\text { Constant-interpolated } \\
\text { for } 2001\end{array}$ & OECD \\
\hline Financial Structure & $\begin{array}{l}\text { Private Credit by } \\
\text { Deposit Money Banks } \\
\text { to GDP/ Stock market } \\
\text { total value traded to } \\
\text { GDP }\end{array}$ & $\begin{array}{l}\text { A } \\
1960-1997\end{array}$ & $\begin{array}{l}\text { Either nominator or } \\
\text { denominator were } \\
\text { interpolated } \\
\text { backwards in some } \\
\text { cases, and the } \\
\text { average for the } 3 \text { rd } \\
\text { period was } \\
\text { approximated by the } \\
\text { average 1993-1997 } \\
\text { only }\end{array}$ & $\begin{array}{l}\text { World Bank } \\
\text { (1999) }\end{array}$ \\
\hline ERM membership & Dummy variable & & $\begin{array}{l}\text { Zero, if not ERM } \\
\text { member; otherwise a } \\
\text { positive value } \leq 1 \\
\text { corresponding to the } \\
\text { weight of a period of } \\
\text { being ERM member }\end{array}$ & \\
\hline
\end{tabular}


Table 6: Business cycle correlation with Germany

\begin{tabular}{|c|c|c|c|c|c|c|c|c|c|}
\hline & 1 & 2 & 3 & 4 & 5 & 6 & 7 & $8^{1)}$ & 9 \\
\hline Trade instrumented & $\begin{array}{l}0.73^{*} \\
(1.69)\end{array}$ & & $\begin{array}{c}0.47 \\
(1.12)\end{array}$ & $\begin{array}{c}0.45 \\
(1.10)\end{array}$ & $\begin{array}{l}0.74 * \\
(1.71)\end{array}$ & $\begin{array}{c}0.62^{+} \\
(1.57)\end{array}$ & $\begin{array}{c}0.31 \\
(0.71)\end{array}$ & $\begin{array}{l}-0.83^{+} \\
(1.63)\end{array}$ & \\
\hline Trade share & & $\begin{array}{l}4.56^{*} \\
(1.94)\end{array}$ & & & & & & & \\
\hline $\begin{array}{l}\text { Labour market } \\
\text { flexibility (NAWRU) }\end{array}$ & $\begin{array}{l}1.97^{+} \\
(1.44)\end{array}$ & & & & & & & & \\
\hline $\begin{array}{l}\text { Relative labour } \\
\text { market flexibility }\end{array}$ & & $\begin{array}{l}3.32^{+} \\
(1.63)\end{array}$ & & & & & & & \\
\hline Industrial structure & & & $\begin{array}{c}0.47 \\
(0.17)\end{array}$ & & & & & & \\
\hline $\begin{array}{l}\text { Relative industrial } \\
\text { structure }\end{array}$ & & & & $\begin{array}{l}-1.54 \\
(1.07)\end{array}$ & & & & & \\
\hline Financial structure & & & & & $\begin{array}{l}-0.05^{+} \\
(1.52)\end{array}$ & & & & \\
\hline $\begin{array}{l}\text { Relative financial } \\
\text { structure }\end{array}$ & & & & & & $\begin{array}{l}-0.12 * \\
(1.77)\end{array}$ & $\begin{array}{l}-0.10^{+} \\
(1.61)\end{array}$ & $\begin{array}{c}-0.23 * * * \\
(3.80)\end{array}$ & $\begin{array}{l}-0.09^{+} \\
(1.50)\end{array}$ \\
\hline $\begin{array}{l}\text { Relative share of oil } \\
\text { imports }\end{array}$ & & & & & & & $\begin{array}{c}-12.99 * * \\
(1.97)\end{array}$ & $\begin{array}{c}-12.74 * * \\
(2.50)\end{array}$ & $\begin{array}{c}-14.79 * * \\
(2.44)\end{array}$ \\
\hline $\begin{array}{l}\mathrm{R}^{2} \text { overall } \\
\text { Obs. (countries) }\end{array}$ & $\begin{array}{c}0.47 \\
27(9)\end{array}$ & $\begin{array}{c}0.51 \\
27(9)\end{array}$ & $\begin{array}{c}0.43 \\
27(9)\end{array}$ & $\begin{array}{c}0.45 \\
27(9)\end{array}$ & $\begin{array}{c}0.48 \\
27(9)\end{array}$ & $\begin{array}{c}0.50 \\
27(9)\end{array}$ & $\begin{array}{c}0.57 \\
27(9)\end{array}$ & $\begin{array}{c}0.75 \\
24(8)\end{array}$ & $\begin{array}{c}0.55 \\
27(9)\end{array}$ \\
\hline
\end{tabular}

Note: The dependent variable is the correlation between deviation cycles of each country and Germany. Averages over three time periods are considered, 1970-1979, 1980-1992, and 1993-2001. Relative variables are defined as the absolute value of the difference between corresponding variables of each country and Germany. For definitions and sources of the variables, see Appendix. Estimation results from random effects regressions are reported. Time fixed effects for period 2 is included showing a significant negative impact (not reported). Dummy variables for EU and ERM membership are never significant (not reported). $t$-values in brackets. $* * *\left(* *,{ }^{*},{ }^{+}\right)=$significant at $1(5,10,15)$-percent level. 1) The country sample does not include Austria. 
Table 7: Business cycle correlation with the US

\begin{tabular}{|c|c|c|c|c|c|c|c|c|c|}
\hline & 1 & 2 & 3 & 4 & 5 & 6 & 7 & $8^{1)}$ & 9 \\
\hline Trade instrumented & $\begin{array}{l}1.41^{* * *} \\
(2.72)\end{array}$ & & $\begin{array}{c}1.79 * * * \\
(3.37)\end{array}$ & $\begin{array}{c}1.52 * * * \\
(3.08)\end{array}$ & $\begin{array}{l}1.01^{*} \\
(1.82)\end{array}$ & $\begin{array}{c}0.63 \\
(1.09)\end{array}$ & $\begin{array}{l}1.63 * * \\
(2.19)\end{array}$ & $\begin{array}{c}1.37 \\
(0.97)\end{array}$ & \\
\hline Trade share & & $\begin{array}{l}3.07 * * \\
(2.53)\end{array}$ & & & & & & & \\
\hline $\begin{array}{l}\text { Labour market } \\
\text { flexibility (NAWRU) }\end{array}$ & $\begin{array}{l}-0.76 \\
(0.57)\end{array}$ & & & & & & & & $\begin{array}{c}-4.37 * * * \\
(3.46)\end{array}$ \\
\hline $\begin{array}{l}\text { Relative labour } \\
\text { market flexibility }\end{array}$ & & $\begin{array}{l}-0.95 \\
(0.48)\end{array}$ & & & & & & & \\
\hline Industrial structure & & & $\begin{array}{l}2.88^{*} \\
(1.86)\end{array}$ & & & & & & \\
\hline $\begin{array}{l}\text { Relative industrial } \\
\text { structure }\end{array}$ & & & & $\begin{array}{l}3.02^{*} \\
(1.73)\end{array}$ & & & & & \\
\hline Financial structure & & & & & $\begin{array}{l}-0.05^{+} \\
(1.51)\end{array}$ & & & & \\
\hline $\begin{array}{l}\text { Relative financial } \\
\text { structure }\end{array}$ & & & & & & $\begin{array}{c}-0.12 * * \\
(2.30)\end{array}$ & $\begin{array}{l}-0.08^{+} \\
(1.61)\end{array}$ & $\begin{array}{l}-0.09^{+} \\
(1.50)\end{array}$ & $\begin{array}{c}-0.25 * * * \\
(5.22)\end{array}$ \\
\hline $\begin{array}{l}\text { Relative share of oil } \\
\text { imports }\end{array}$ & & & & & & & $\begin{array}{c}-15.52 * * \\
(1.97)\end{array}$ & $\begin{array}{c}-14.93^{*} \\
(1.67)\end{array}$ & \\
\hline ERM membership & & & & & & & & & $\begin{array}{l}0.22 * \\
(1.75)\end{array}$ \\
\hline $\mathrm{R}^{2}$ overall & 0.32 & 0.32 & 0.40 & 0.39 & 0.37 & 0.44 & 0.52 & 0.44 & 0.46 \\
\hline Obs. (countries) & $27(9)$ & $27(9)$ & $27(9)$ & $27(9)$ & $27(9)$ & $27(9)$ & $27(9)$ & $24(8)$ & $27(9)$ \\
\hline
\end{tabular}

Note: The dependent variable is the correlation between deviation cycles of each country and US. Averages over three time periods are considered, 1970-1979, 1980-1992, and 1993-2001. Relative variables are defined as the absolute value of the difference between corresponding variables of each country and US. For definitions and sources of the variables, see Appendix. Estimation results from random effects regressions are reported. Time fixed effects for period 2 is included showing a significant negative impact (not reported). $t$-values in brackets. $* * *\left(* *, *{ }^{+}\right)=$significant at $1(5,10$, 15)-percent level. ${ }^{1)}$ The country sample does not include Canada. 
Appendix B. Cluster analysis over business cycle characteristics

Chart B1: Hierarchical average-linkage cluster tree (dendrogram) using Euclidean (L2) dissimilarity measure based on business cycle characteristics, full sample 1970-2001

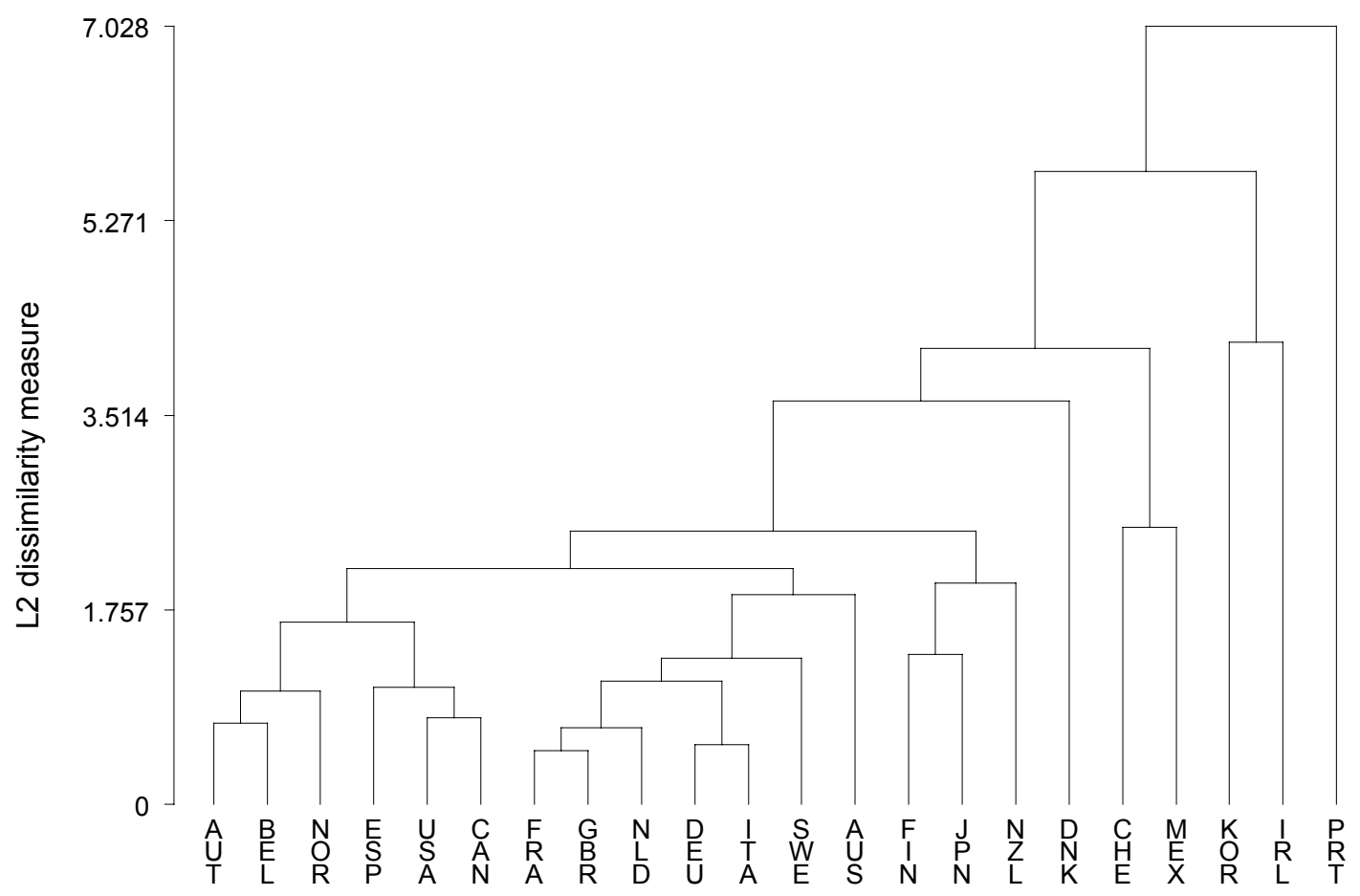


Appendix C.

Chart C1: Business Cycle Cross Correlation (OECD trade cycle database), pre-ERM period 1961:1-1979:3

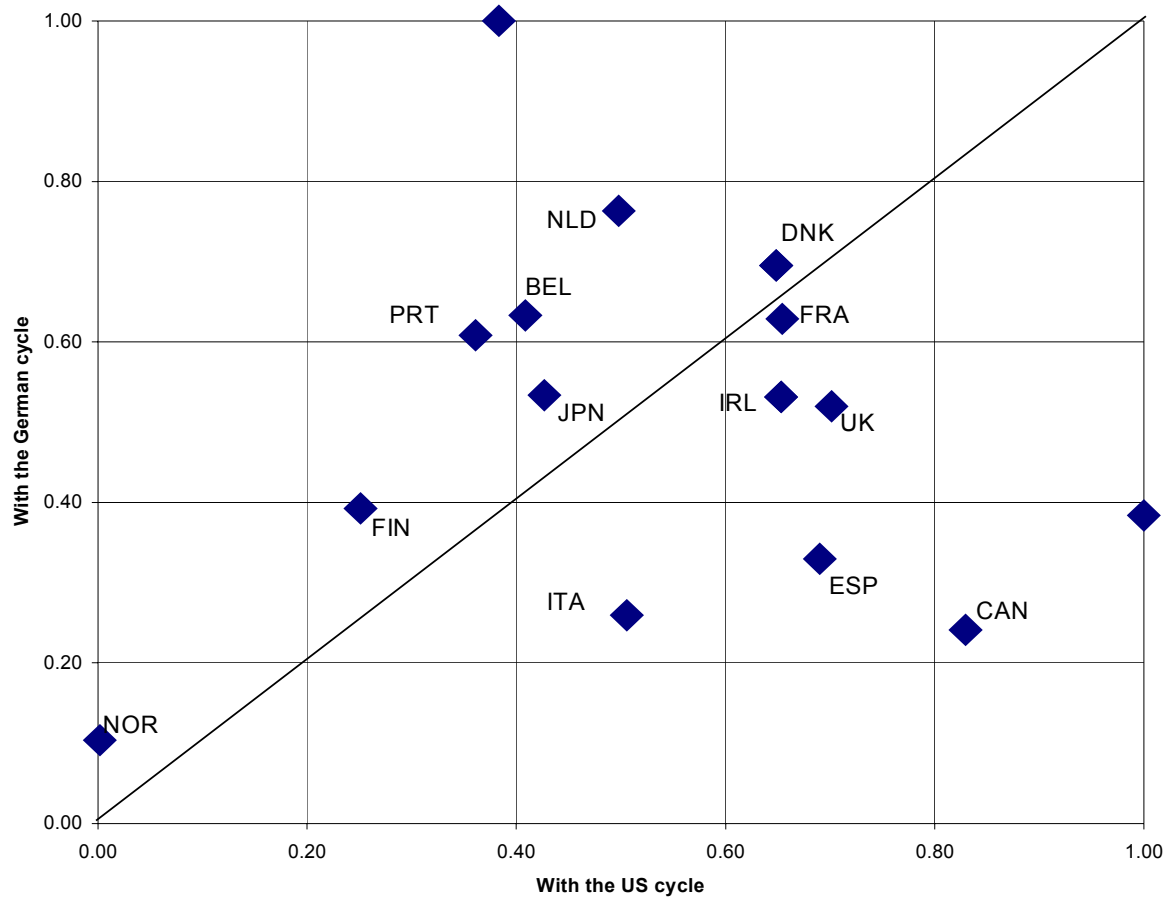

Chart C2: Business Cycle Cross Correlation (OECD trade cycle database), ERM period 1979:4-1993:12

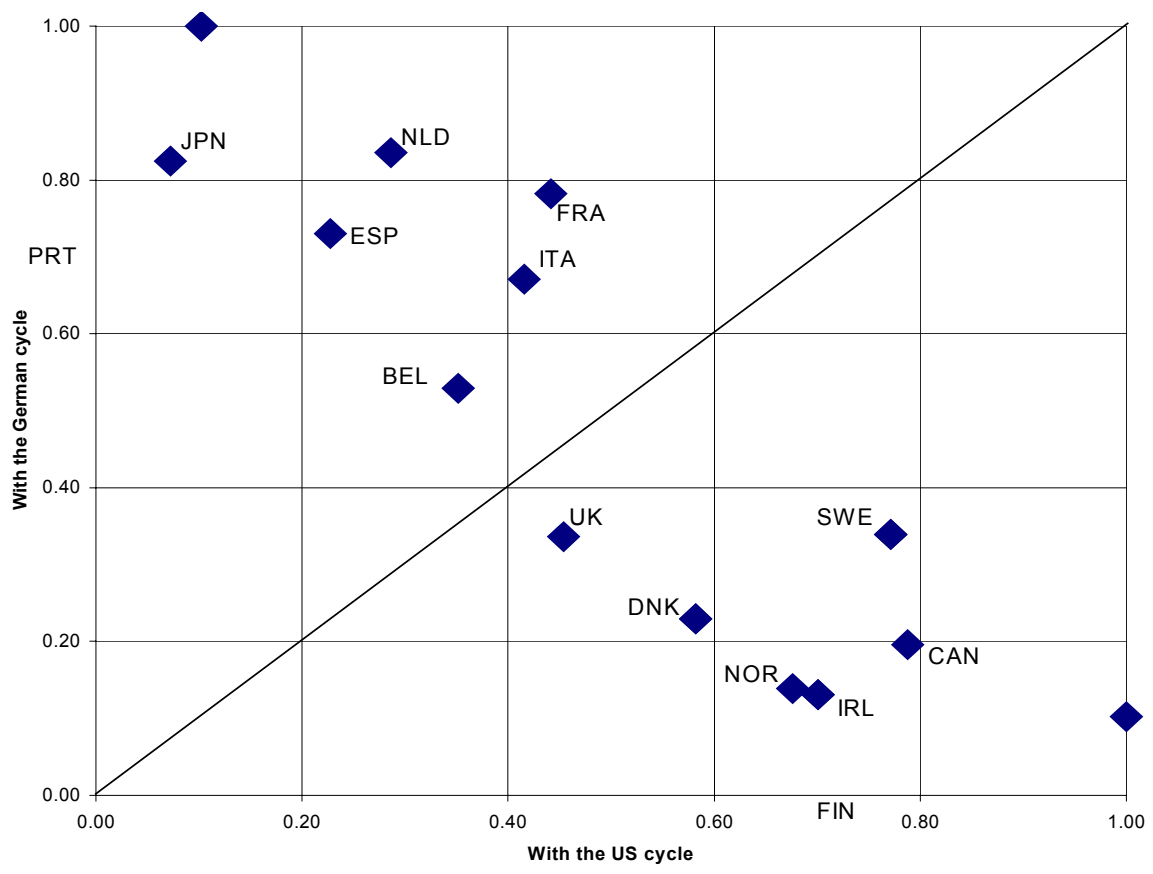


Chart C3: Business Cycle Cross Correlation (OECD trade cycle database), post-ERM period 1994:1-2000:12

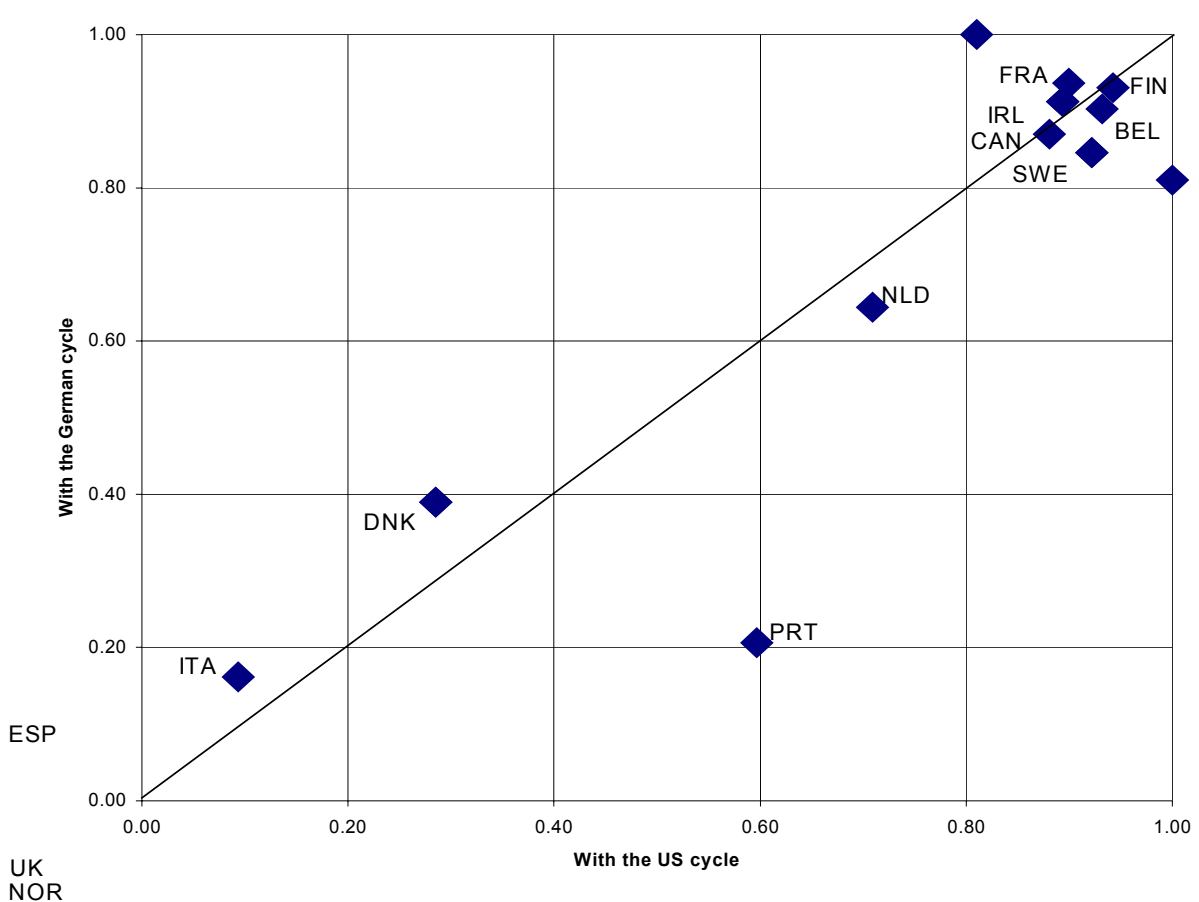


Chart C4: Correlation to Germany and the US, 1970-1979

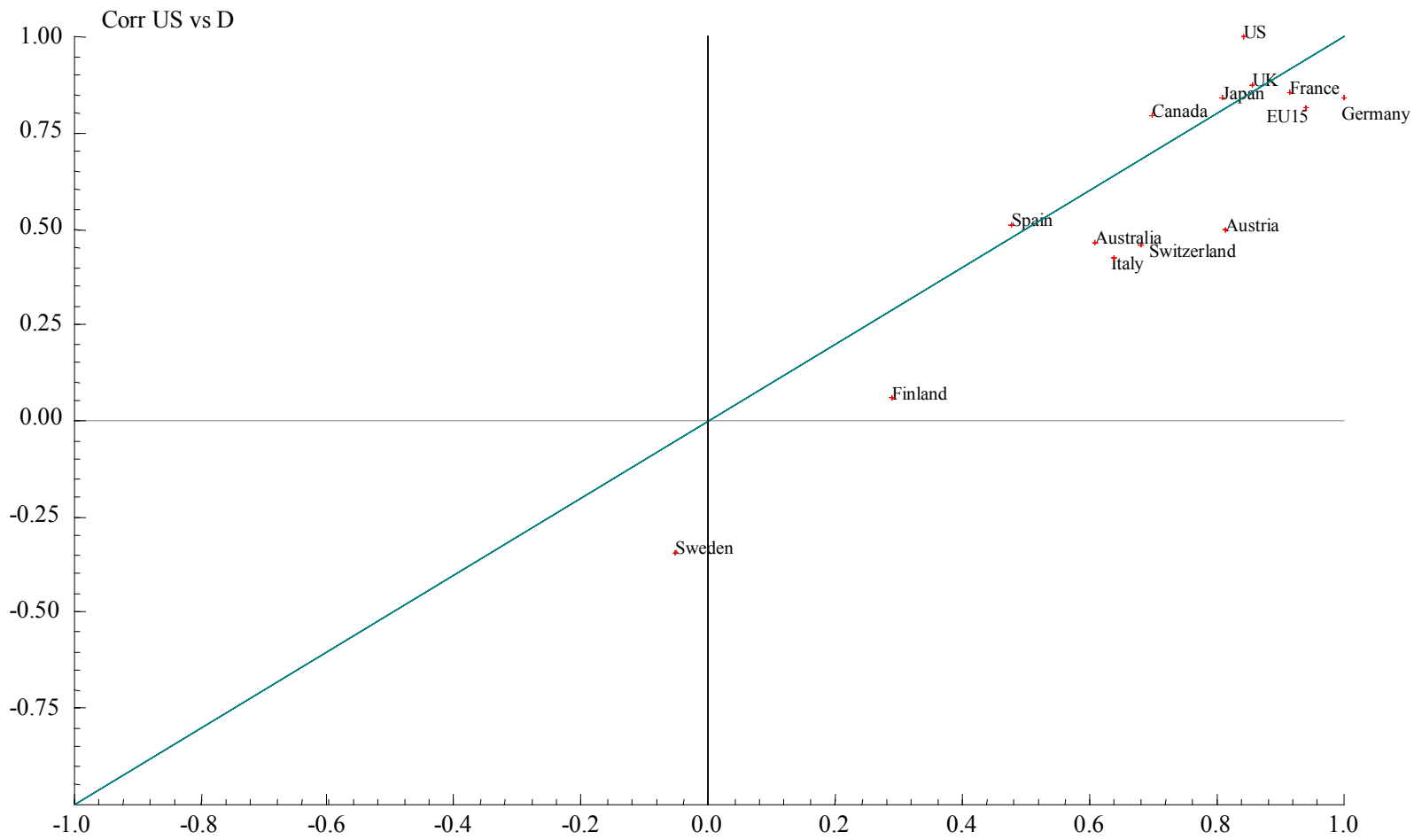

Chart C5: Correlation to Germany and the US, 1980-1992

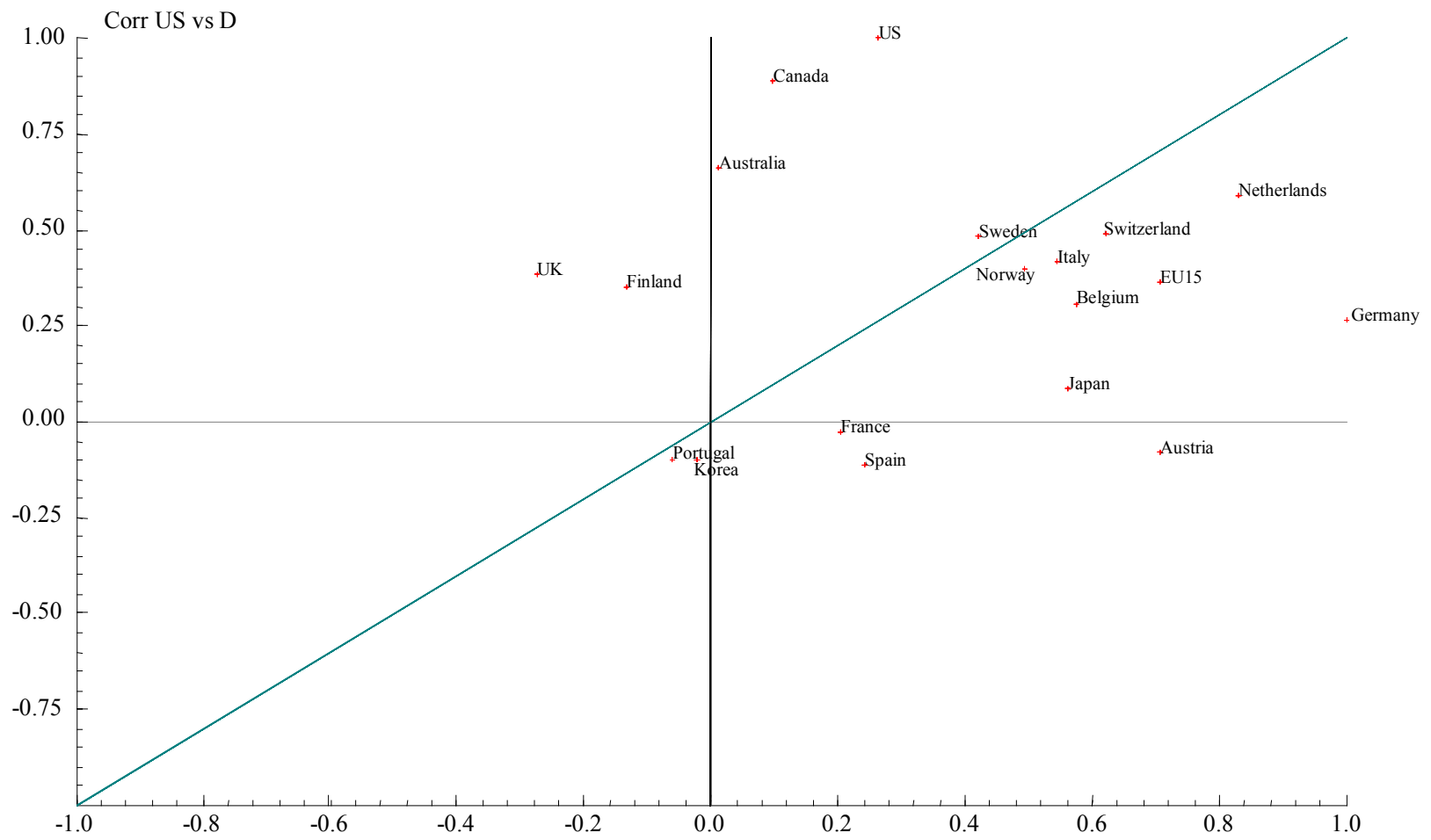


Chart C6: Correlation to Germany and the US, 1993-2001

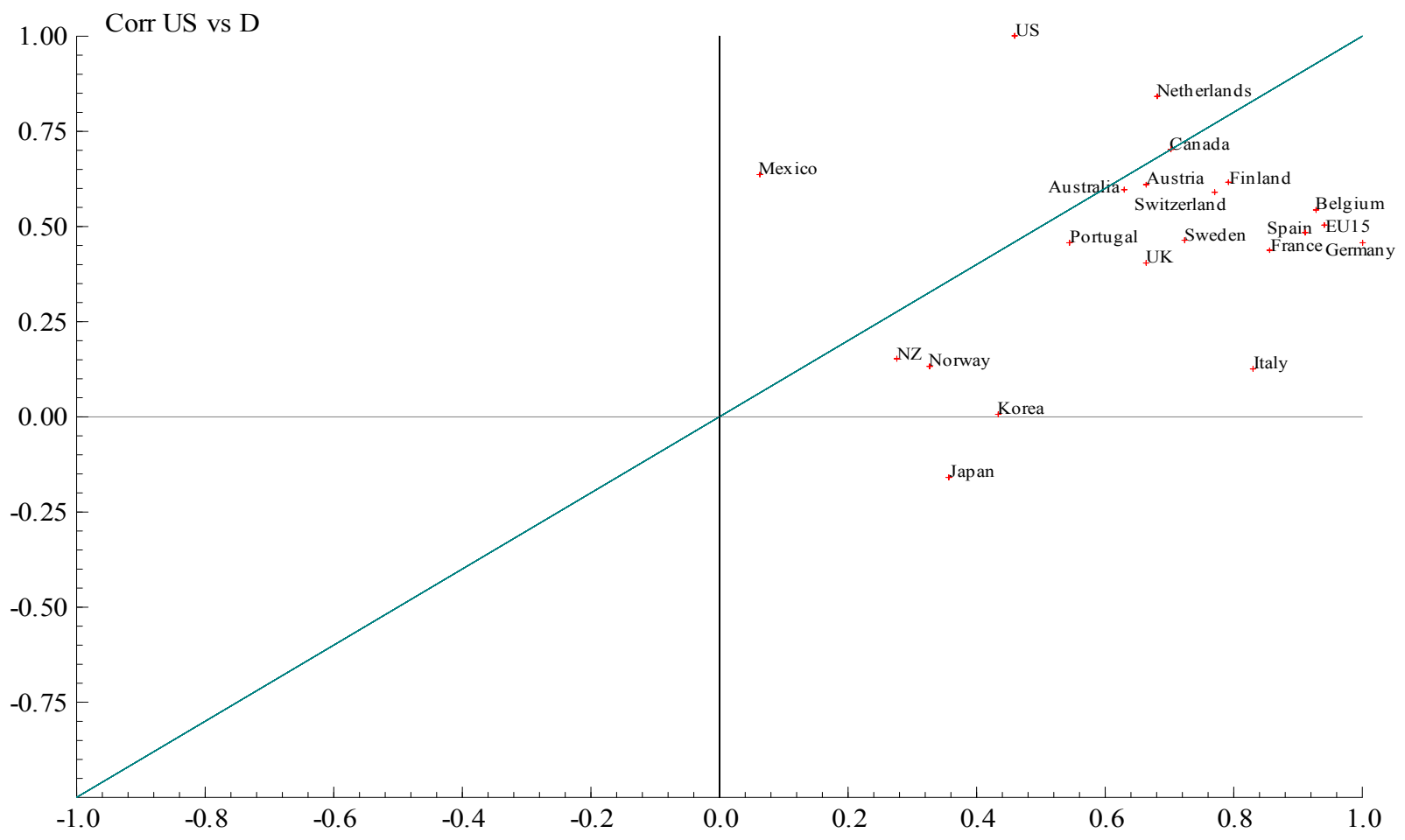


Frankel, J. and A. Rose (1998) "The Endogeneity of the Optimum Currency Area Criteria”, The Economic Journal, 108 (July), 1009-1025

Holden, S. and R. Nymoen (2001) "Measuring Structural Unemployment: NAWRU Estimates in the Nordic countries", mimeo, http://folk.uio.no/sholden/NAWEU\%20Feb\%202001.pdf (published Scandinavian Journal of Economics 104 (1), 87$104,2002)$

Fagan, G., Henry, J. and R. Mestre (2001) An Area-Wide Model (AWM) for the Euro Area, Working Paper No. 42, European Central Bank

World Bank (1999) “A New Database on Financial Development and Structure”, T. Beck, A. Demirguc-Kunt, R. Levine, http://www.worldbank.org/research/projects/ finstructure/database.htm 


\section{CESifo Working Paper Series}

(for full list see www.cesifo.de)

990 M. Hasham Pesaran and Allan Timmermann, Small Sample Properties of Forecasts from Autoregressive Models under Structural Breaks, July 2003

991 Hyun Park, Apostolis Philippopoulos and Vangelis Vassilatos, On the Optimal Size of Public Sector under Rent-Seeking competition from State Coffers, July 2003

992 Axel Ockenfels and Alvin E. Roth, Late and Multiple Bidding in Second Price Internet Auctions: Theory and Evidence Concerning Different Rules for Ending an Auction, July 2003

993 Pierre Salmon, The Assignment of Powers in an Open-ended European Union, July 2003

994 Louis N. Christofides and Chen Peng, Contract Duration and Indexation in a Period of Real and Nominal Uncertainty, July 2003

995 M. Hashem Pesaran, Til Schuermann, Björn-Jakob Treutler, and Scott M. Weiner, Macroeconomic Dynamics and Credit Risk: A Global Perspective, July 2003

996 Massimo Bordignon and Sandro Brusco, On Enhanced Cooperation, July 2003

997 David F. Bradford, Addressing the Transfer-Pricing Problem in an Origin-Basis X Tax, July 2003

998 Daniel Gros, Who Needs Foreign Banks?, July 2003

999 Wolfram Merzyn and Heinrich W. Ursprung, Voter Support for Privatizing Education: Evidence on Self-Interest and Ideology, July 2003

1000 Jo Thori Lind, Fractionalization and the Size of Government, July 2003

1001 Daniel Friedman and Donald Wittman, Litigation with Symmetric Bargaining and TwoSided Incomplete Information, July 2003

1002 Matthew Clarke and Sardar M. N. Islam, Health Adjusted GDP (HAGDP) Measures of the Relationship Between Economic Growth, Health Outcomes and Social Welfare, July 2003

1003 Volker Grossmann, Contest for Attention in a Quality-Ladder Model of Endogenous Growth, August 2003

1004 Marcel Gérard and Joan Martens Weiner, Cross-Border Loss Offset and Formulary Apportionment: How do they affect multijurisdictional firm investment spending and interjurisdictional tax competition?, August 2003 
1005 Burkhard Heer, Nonsuperneutrality of Money in the Sidrauski Model with Heterogeous Agents, August 2003

1006 V. Anton Muscatelli, Piergiovanna Natale, and Patrizio Tirelli, A Simple and Flexible Alternative to the Stability and Growth Pact Deficit Ceilings. Is it at hand?, August 2003

1007 Reto Foellmi and Josef Zweimüller, Inequality and Economic Growth: European Versus U.S. Experiences, August 2003

1008 James S. Costain and Michael Reiter, Business Cycles, Unemployment Insurance, and the Calibration of Matching Models, August 2003

1009 Marco Runkel, Optimal Contest Design when the Designer's Payoff Depends on Competitive Balance, August 2003

1010 Donald O. Parsons, Torben Tranaes and Helene Bie Lilleør, Voluntary Public Unemployment Insurance, August 2003

1011 Rüdiger Pethig and Andreas Wagener, Profit Tax Competition and Formula Apportionment, August 2003

1012 Johan Willner, Privatisation and Public Ownership in Finland, August 2003

1013 Seppo Kari and Jouko Ylä-Liedenpohja, Taxation and Valuation of International Real Investments, August 2003

1014 James Heckman, Rosa Matzkin and Lars Nesheim, Simulation and Estimation of Hedonic Models, August 2003

1015 Biswa N. Bhattacharyay, Towards a Macro-Prudential Leading Indicators Framework for Monitoring Financial Vulnerability, August 2003

1016 J. Stephen Ferris and Stanley L. Winer, Searching for Keynes: With Application to Canada, 1870-2000, August 2003

1017 Massimo Bordignon, Luca Colombo and Umberto Galmarini, Fiscal Federalism and Endogenous Lobbies’ Formation, August 2003

1018 Annette Alstadsæter, The Dual Income Tax and Firms’ Income Shifting through the Choice of Organizational Form and Real Capital Investments, August 2003

1019 Peter Fredriksson and Bertil Holmlund, Optimal Unemployment Insurance Design: Time Limits, Monitoring, or Workfare?, August 2003

1020 Kashif S. Mansori, Following in their Footsteps: Comparing Interest Parity Conditions in Central European Economies to the Euro Countries, August 2003

1021 Christoph Borgmann and Matthias Heidler, Demographics and Volatile Social Security Wealth: Political Risks of Benefit Rule Changes in Germany, August 2003 
1022 Kjell Erik Lommerud, Bjørn Sandvik and Odd Rune Staume, Good Jobs, Bad Jobs and Redistribution, August 2003

1023 Patrick Karl O’Brien, The Governance of Globalization: The Political Economy of Anglo-American Hegemony, 1793-2003, September 2003

1024 Antonio Ciccone and Giovanni Peri, Skills' Substitutability and Technological Progress: U.S. States 1950-1990, September 2003

1025 Bjørn Sandvik, Optimal Taxation and Normalisations, September 2003

1026 Massimo Bordignon and Gilberto Turati, Bailing Out Expectations and Health Expenditure in Italy, September 2003

1027 José A. Herce, Namkee Ahn, Ricard Génova, and Joaquín Pereira, Bio-Demographic and Health Aspects of Ageing in the EU, September 2003

1028 John Komlos and Marieluise Baur, From the Tallest to (One of) the Fattest: The Enigmatic Fate of the American Population in the $20^{\text {th }}$ Century, September 2003

1029 Stefan Napel and Mika Widgrén, Bargaining and Distribution of Power in the EU's Conciliation Committee, September 2003

1030 Kai Li and Dale J. Poirier, Relationship Between Maternal Behavior During Pregnancy, Birth Outcome, and Early Childhood Development: An Exploratory Study, September 2003

1031 Ivar Ekeland, James J. Heckman, and Lars Nesheim, Identifcation and Estimation of Hedonic Models, September 2003

1032 Kjetil Bjorvatn and Alexander W. Cappelen, Decentralization and the Fate of Minorities, September 2003

1033 Lars-Erik Borge and Jørn Rattsø, The Relationships Between Costs and User Charges: The Case of a Norwegian Utility Service, September 2003

1034 Maureen Were and Nancy N. Nafula, An Assessment of the Impact of HIV/AIDS on Economic Growth: The Case of Kenya, September 2003

1035 A. Lans Bovenberg, Tax Policy and Labor Market Performance, September 2003

1036 Peter Birch Sørensen, Neutral Taxation of Shareholder Income: A Norwegian Tax Reform Proposal, September 2003

1037 Roberta Dessi and Sheilagh Ogilvie, Social Capital and Collusion: The Case of Merchant Guilds, September 2003

1038 Alessandra Casarico and Carlo Devillanova, Capital-skill Complementarity and the Redistributive Effects of Social Security Reform, September 2003 
1039 Assaf Razin and Efraim Sadka, Privatizing Social Security Under Balanced-Budget Constraints: A Political-Economy Approach, September 2003

1040 Michele Moretto, Paolo M. Panteghini, and Carlo Scarpa, Investment Size and Firm’s Value under Profit Sharing Regulation, September 2003

1041 A. Lans Bovenberg and Peter Birch Sørensen, Improving the Equity-Efficiency Tradeoff: Mandatory Savings Accounts for Social Insurance, September 2003

1042 Bas van Aarle, Harry Garretsen, and Florence Huart, Transatlantic Monetary and Fiscal Policy Interaction, September 2003

1043 Jerome L. Stein, Stochastic Optimal Control Modeling of Debt Crises, September 2003

1044 Thomas Stratmann, Tainted Money? Contribution Limits and the Effectiveness of Campaign Spending, September 2003

1045 Marianna Grimaldi and Paul De Grauwe, Bubbling and Crashing Exchange Rates, September 2003

1046 Assar Lindbeck and Dennis J. Snower, The Firm as a Pool of Factor Complementarities, September 2003

1047 Volker Grossmann, Firm Size and Diversification: Asymmetric Multiproduct Firms under Cournot Competition, September 2003

1048 Dan Anderberg, Insiders, Outsiders, and the Underground Economy, October 2003

1049 Jose Apesteguia, Steffen Huck and Jörg Oechssler, Imitation - Theory and Experimental Evidence, October 2003

1050 G. Abío, G. Mahieu and C. Patxot, On the Optimality of PAYG Pension Systems in an Endogenous Fertility Setting, October 2003

1051 Carlos Fonseca Marinheiro, Output Smoothing in EMU and OECD: Can We Forego Government Contribution? A Ris Sharing Aproach, October 2003

1052 Olivier Bargain and Nicolas Moreau, Is the Collective Model of Labor Supply Useful for Tax Policy Analysis? A Simulation Exercise, October 2003

1053 Michael Artis, Is there a European Business Cycle?, October 2003 